\title{
Hypocephalus in Ancient Egyptian Religion
}

\section{Mofida H. El Weshahy}

\author{
Faculty of Tourism and Hotels \\ Suez Canal University
}

\author{
Rasha M. Omran \\ Faculty of Tourism and Hotels \\ Fayoum University
}

\begin{abstract}
Hypocephalus is a small round shaped disk, made of plastered linen, papyrus, bronze, gold, wood, and either clay. Since the Late Period onwards; ancient Egyptians used to place such round desks under the heads of their deceased. This unusual disk, covered with extraordinary images and texts, is known as "Hypocephalus," which is a Greek word interpreted as 'that which is below the head', referring to its religious significance. This unusual religious pillow enabled the deceased to identify himself to the sun god by the light coming through. It was believed to magically protect the deceased, light and warmth envelope the head and body, so imposes the deceased divinity. The talisman on the disk with the mysterious shapes of the creator god Ra protect the deceased in the afterlife. It was often inscribed with chapter 162 of the Book of the Dead, consecrated to give warmth under the head of the dignified one. The current research was carried out to spot light on the etymology of the word 'hypocephalus', its symbolism as an amulet, and to clarification of scenes on both sides of the Hypocephalus. Preliminary results revealed the etymology of Hypocephalus literally 'that which is below the head', was placed between the head of the mummy and the funerary headrest. The earliest examples appeared during the Late Periods; they were simple inscribed pieces of papyrus, clay, bronze, gold, wood as well as stucco linen with vignettes' decorations. The hieroglyphic inscriptions run around the disk framework. This study aims to;

- Shed light on the etymology of the word hypocephalus.

- $\quad$ Illuminate the religious significance of the hypocephalus as an amulet.

- $\quad$ Describe the representations of baboons carved on the hypocephalus.

- Focus on the several representations of baboons and their different functions.

- Spot light on the symbolism of baboons which are varied from a hypocephalus to another.

- $\quad$ Analyze the relation of scenes depicted on the disk with the purpose of the hypocephalus.

- Count God Ra forms and identify the object due to the ancient Egyptian religious concepts.
\end{abstract}

Key Words: Hypocephalus, Round Disk, Late Periods, Amulet, Ancient Egyptian Religion, Book of the Dead.

\section{Methodology}

Religious approach is applied to show the significance, functions, and relations of baboons' representations on the hypocephalus to the different forms of the sun God Ra. Descriptive approach is applied to describe the figures on the hypocephalus in general, and focuses on baboons representations. In addition, analytic approach is applied to explain and make detailed comments on the selected figures of baboons.

\section{Introduction}

Hypocephalus is a small round disk; occasionally made of different materials as plastered linen, papyrus, bronze, gold, wood and clay. This odd panel with its alien images and texts is known as "Hypocephalus", which is a Greek word means 'that which is below the head'. Ancient Egyptians started to place it under the heads of their deceased from the Late Period and onwards. Hypocephalus is an unusual religious pillow with solar significance associated the deceased with the sun god Ra in the netherworld. It consists of two sides; a blank one, while the upper side -upon which the head rested- is covered with various scenes and inscriptions. On other cases; various forms of sun god Ra occupy the pillow's two sides. It was believed, hypocephalus magically protected the deceased, encircled his head and body with light and warmth. The panel's figures showed mysterious shapes of the creator god bestowing protection to the deceased in the afterlife. The circular panel was often inscribed with vignettes of Chapter 162 in the Book of the Dead consecrated to provide warmness beneath the dignified person's head. ${ }^{1}$

\section{Religious Believes and Miniatures during the Late Period}

During the Late Period; religious beliefs were designed of illusions, magic, and religious superstitions, took religion form and science, this was unknown in the eras of prosperity. Religion basically influenced the Egyptians' life; so the historian Herodotus mentioned that the Egyptians were more pious than others. ${ }^{2}$

During this period, ancient Egyptian religion became more mysterious than before. ${ }^{3}$ This was often obvious; such as the Metternich stela; contains many interesting inscriptions and figures very difficult to interpret and so are the magical purposes of the symbols. ${ }^{4}$ 
Since the beginning of the ancient Egyptian history and until the late periods; ancient Egyptian art was associated with religion. There is no art, but it stems from religious beliefs to draw closer to God. ${ }^{5}$ Minor Arts were measured one of the oldest arts known in the ancient Egyptian civilization. Late Periods Arts showed a high skill in terms of writing and distinctive shapes of the gods. ${ }^{6}$ This is obvious in the integration of more than one deity in an image. This has been developed to re even five ones in an image. ${ }^{7}$

Late Periods minor arts varied; such as jewelry, scarabs, seals as well as hypocephalus. This was considered one of the most important minor arts with the religious character represent beliefs and superstitions of its period. ${ }^{8}$ It is essential to mention; amulets in ancient Egypt were used by both living and deceased to provide them with protection and magical power. Funeral amulets were made to the burial purposes; they were enveloped with the deceased within linen bandages to protect him in the underworld journey, and provide with all netherworld supplies. ${ }^{9}$ Some Chapters in the Book of the Dead specified amulet's material, and the spell to be recited. They represented the amulet's effect, and in some cases added the vignettes illustrated on many amulets; like the heart amulet. ${ }^{10}$

By examining the Late Periods mummies; the ancient Egyptians draw a cow upon papyrus and lay it beneath the deceased head, besides, the magical texts inscribed upon. Later, the cow gold figure was superseded, it was fastened on the deceased neck as an amulet known as Hypocephalus. ${ }^{11}$ The Late Periods, accurately, the Saite Dynasty 664 B.C, was the beginning of utilizing Hypocehalus as an amulet. ${ }^{12}$ Such function of Hypocehalus continued later until the Christian epoch. ${ }^{13}$

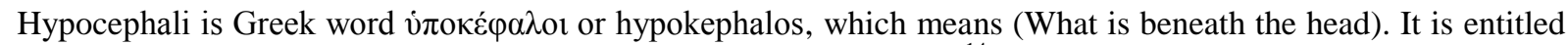
in hieroglyphs as Xr Tp; referring to its position below the mummy's head. ${ }^{14}$ Hypocephalus is a small round pillow, of different materials. This was believed to envelope the deceased mummy with warmness, which in turn enable the deceased soul to reach the eternity like deities in the netherworld. ${ }^{15}$ All the information about hypocephalus was derived from the Saite version or the late revised text of the Book of the Dead, especially chapter 162, concentrates on location, construction, as well as, the purpose of the hypocephalus. ${ }^{16}$

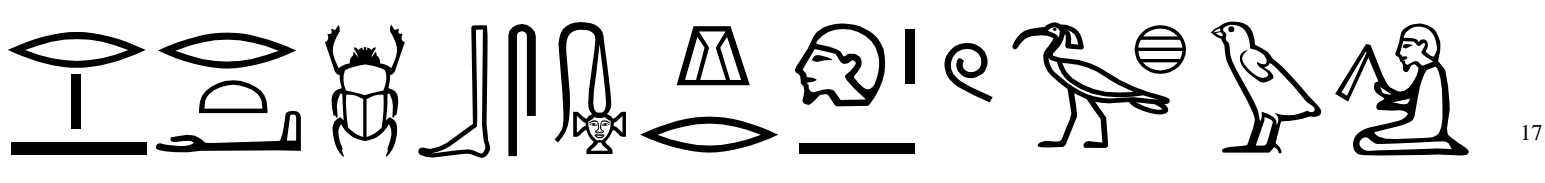

Transliteration

rA $\quad \operatorname{rdi}(\mathrm{t}) \quad \mathrm{xpr} \quad$ bs $\quad \mathrm{Xr} \quad$ tp $\quad$ Axw

\section{Translation}

The ritual caused a heat to be glowing under the head of the blessed one (OR) a spell for letting a flame arise under the head of the glorified deceased.

It is believed, foreign concepts influenced this section of Chapter 162; like Semitic, due to the very strange words written in. ${ }^{18}$ In Ancient Egypt, hypocephalus was not utilized on a large scale, however, and it was found in certain upper Egyptian priests' tombs. Inscriptions and scenes applied on, refer to the ancient Egyptian belief in the afterlife and eternity for the soul of the deceased. ${ }^{19}$ Moreover, in ancient Egyptian conception, Shu and Horus eye were the symbols assumed to keep the normal warmness to the mummy until resurrection. The main part represented the eye mesh and hieroglyphic inscriptions run around, indicating the various aspects of God Amon-Ra. ${ }^{20}$

Hypocephalus was of papyrus, stucco - linen, wood, gold, clay as well as bronze. ${ }^{21}$ Bronze was widely utilized in minor arts, especially, during the Late Periods, referring to the development of bronze masterpieces. ${ }^{22}$ Furthermore, $^{2}$ bronze or Hsmn in ancient Egyptian language, ${ }^{23}$ was used instead of gold, which, was the symbol of the sun god Ra and eternity due to its color, brightness and imperishable nature. As a result, bronze was regarded as symbol of eternal life and resurrection in the netherworld. ${ }^{24}$

Hypocephalus showed all things in the world ed by the sun. In other words, it is divided into two opposing sections, each, separated to several registers including the whole world on earth, represented in the upper part containing the secret form of the sun deity with four heads. This reflect his omnipotence and in the afterlife as represented in lower part containing the celestial cow. ${ }^{25}$ The point of the meeting of the day and night boats refers to passing of the deceased soul to the eternal life in the netherworld. According to the book of the 'imy dwAt' the sun god Ra transformed itself during the night twelve hours to be shown again in the morning, taking the xpr scarab form. Therefore; when this rounded panel was put under the deceased head, it enables the soul to follow the sun god in journey and face its same hopefully fate in resurrection and eternity. ${ }^{26}$

All the figures and scenes on Hypocephali indicate to the ancient Egyptians' desire of rebirth, resurrection, and eternity after death as a divine creature. ${ }^{27}$ This message was transmitted by a variety of animals, figures, and deities refer to the ancient Egyptian conception, expressing ideas through specific and concrete representations. These were forms and aspects of the supreme god $\mathrm{Ra}$, which helped in translating the ancient Egyptian religious ideas, especially, during the Late Periods. ${ }^{28}$ 
There are many classifications of hypocephali. According to Uranic, hypocephali are classified into two types; theban type in which the hypocephalus contains three horizontal registers with few inscriptions beside the scenes, ${ }^{29}$ and DbA ty type ${ }^{30}$ referring to god Osiris title with which the text begins. In addition, Gee classified them into six styles. Conclusively; there are many types of hypocephali; they are almost similar; except for tiny details. ${ }^{31}$

This research deals with forty one hypocephali; exhibited in different museums all over the world. This study focuses on the baboons' scenes; specially their forms, positions, locations, total number, and their number flanking the seated four - headed god.

In the Old Kingdom, the sacred baboon ${ }^{32}$ or ape was associated with the god DHwty patron of writing and wisdom. Moreover, it was a manifestation of the moon god DHwty. It was a very strong relation between the baboons and the sun in Ancient Egypt because of their curious habit of warming themselves by sun rays at the beginning of the day with raised paws after a very cold night. It was believed these animals adored the solar sphere. ${ }^{33}$

The association between the sun god $\mathrm{Ra}$ and the baboons presented in various ways; like the representation of baboons raising their paws at the obelisks' pedestals in worshiping attitude. Moreover, on the facades of some of the temples connected with the sun like the great temple of Abu Simbel; ${ }^{34}$ offer the wDjAt eye as a symbol of god Ra. ${ }^{35}$ In other cases, baboons were depicted in the solar boats sitting with god $\mathrm{Ra}^{36}$

Baboons were depicted in various positions; standing on their four feet, sitting on their hips, as well as standing with raised paws on their hind legs. Baboons were connected with the underworld, represented in chapter 155 of the Dead, depicted sitting around the four corners of the netherworld fire lake. ${ }^{37}$

In the book of the imy dwAt, baboon was the guardian of the underworld's first gate. ${ }^{38}$ Moreover, baboon was represented as one of the four sons of god Horus like Hapi or the baboon - headed god forming the upper lid of a viscera jar with the organs of the deceased body. ${ }^{39}$

\section{Doc. 1 Fig. 1}

Bronze Hypocephalus of $\mathrm{Hr}$ wDA from Abydos, British museum. Four registers with different deities; a double face god holding a scepter with wp wAwt and Sokar's boat in the first register, two baboons adoring Amon Ra with four heads of a ram in the second register. In the third register, a child of the sun-god sits on a sky sign between the solar boat and the moon bark, then Nut is shown bending on a scarab. Finely, xpr, Horus-Ra, the head of Khnum ram on a pylon, some magical signs serving the purpose of the Hypocephalus, four sons of Horus facing ihet cow, the wDAt Goddess, Soped in is seated and Nehebkaw in the fourth register. ${ }^{40}$

\section{Doc. 2 Fig. 2}

Plastered - Linen Hypocephalus with no name, British museum. ${ }^{41}$ It has the same description of Doc. 1 except for the disappearance of the seated child of the sun $\mathrm{Ra}$ in third register. ${ }^{42}$

\section{Doc. 3 Fig. 3}

Plastered - Linen Hypocephalus of Neshorpakhered, Thebes, British museum. Three registers contain the double facedgod and two barks of Horus - Ra and Sokar in the first register. Four ram headed - gods with four adoring baboons are in the middle register, and a scarab, four sons of Horus, ihet, the wdjAt goddess and a seated existential deity. The rest of the hypocephalus is damaged. ${ }^{43}$

\section{Doc. 4 Fig. 4}

Plastered - Linen Hypocephalus, British museum. One register includes the cow goddess facing the four sons of Horus, and followed by a fan; symbolizes the sun shade. ${ }^{44}$

\section{Doc. 5 Fig. 5}

Plastered - Linen Hypocephalus of Hsy xb, British museum. Two registers, the first register includes Amon Ra with four heads a ram god ed by four adoring baboons. The second register contains magical signs, four sons of Horus, the cow and the wdjAt goddesses, and a seated deity probably Min facing the snake Nehebkaw.

\section{Doc. 6 Fig. 6}

Plastered - papyrus Hypocephalus, British museum. Three registers; the first register contain two baboons, probably, flanking the four ram headed - god; the second depicts the solar boat with different deities. The third includes the four sons of Horus, the cow and the wdjAt goddesses, as well as, the seated deity with human head and bird's back. ${ }^{46}$

\section{Doc. 7 Fig. 7}

Plastered - Linen Hypocephalus, British museum with three registers. The first register contains the double - headed god flanked with three boats of Sokar, the soul of the deceased and Horus- Ra with the scarab. The second register includes the four ram headed - god flanked by six adoring baboons. The third register depicts scenes of Horus's four sons, MHyt wrt, the eye head goddess, Min seated, and the adoring Nehebkaw with human arms and legs. ${ }^{47}$ 


\section{Doc. 8 Fig. 8}

Plastered - papyrus Hypocephylus, British museum. It is mostly identical to Doc. 7, except for the number of adoring baboons, here, they are six, and the four sons of Horus are seated in this hypocephalus. ${ }^{48}$

\section{Doc. 9 Fig. 9}

Plastered - papyrus Hypocephalus. Incomplete four registers contain Nut bending on a scarab in the third register, as well as, the moon boat with two baboons, one is within a shrine and the other is outside, and offering the wdjAt eye.

\section{Doc. 10 Fig. 10}

Plastered - Linen Hypocephalus of Hr nt it.f, British museum. Two registers; the first depicts a seated child of the sungod on a sky sign, and a boat with several standing gods and goddesses like Thot, Maat, Sekhet, ram headed - god, Shu and Bast. The second register contains a seated four ram - headed god with doubled body, and adorned by eight seated and standing baboons. 49

\section{Doc. 11 Fig. 11}

Bronze Hypocephalus of Dd Hr, Abydos, British museum. This is identical to hypocephalus no.1, except for it is bigger, and the adoring baboons around the four ram headed - god are no more existent. ${ }^{50}$

\section{Doc. 12 Fig. 12}

Plastered - Linen Hypocephalus with verso, Egyptian Museum. The recto side contains three registers; the first represents a ram in the moon bark as a form of Amon Ra with a seated baboon in adoration attitude. The second register contains the four ram - headed deity flanked by two adoring baboons. However, the third register depicts a double faced god holding a stand with wp wAwt, a boat with a seated baboon holding wdjAt eye, and a boat with the damaged figure. $^{51}$

\section{Doc. 13 Fig. 13}

Plastered - Linen Hypocephalus, Egyptian museum. Three registers; the first depicts the four ram - headed god while seated. The second includes ihet, wdjAt goddess, a seated God and Nehebkaw while adoring with human limbs and holding the mystical wdjAt eye. In addition, a boat of Sokar with two outstretched wings is depicted. ${ }^{52}$

\section{Doc. 14 Fig. 14}

Plastered - Linen Hypocephalus, Egyptian museum. Three registers, the first depicts the double - faced god flanked by Sokar boat and the deceased's spirit on a shrine. The middle depicts the seated god with four heads of a ram, flanked by four adoring baboons. The third Register depicts a great bark with a ram headed - god in the middle preceded by Thot, two goddesses, and followed by two human- personified gods as Horus. ${ }^{53}$

\section{Doc. 15 Fig. 15}

Plastered - Linen Hypocephalus, Egyptian museum. This has four registers; the first depicts a double faced - god holding a stand with wp wAwt. On the right, there are two overlapping boats, the topmost one show a hawk upon a pedestal, while the lower one has a big scarab. Behind the god, is another boat containing a mummified shrank wings. The second register depicts four seated ram headed - god flanked by two adoring baboons. In the third register, is the moon bark with two seated baboons; one in the shrine and the other is outside. On the left; is the solar boat with six deities; Horus, two goddesses, a god with the solar disk on his head, a serpent and two other gods around. The fourth register depicts Horus's four sons, the divine cow and WdjAt goddess, the seated god opposite to another figure in adoration attitude. ${ }^{54}$

\section{Doc. 16 Fig. 16}

Plastered - Linen Hypocephalus, Suhag museum with two registers. The first register depicts the solar boat besides a god with the solar disk on his head in the middle, and two goddesses flank him. The other boat includes a big scarab. The second register contains the four ram headed - god. ${ }^{55}$

\section{Doc. 17 Fig. 17}

Plastered - Linen Hypocephalus, Egyptian museum with two registers. The first register depicts a green bark with three seated deities; Isis, Anubis and Nephtys. The second register depicts seven seated deities in red and green color holding knives. $^{56}$

\section{Doc. 18 Fig. 18}

Linen -Hypocephalus with verso side, Petri museum. The recto side is divided into three registers. The first register depicts the solar boat. The second depicts the four ram headed - god flanked by two baboons and two men in adoration attitude. The third register depicts the cow goddess. ${ }^{57}$ 


\section{Doc. 19 Fig. 19}

Linen - Hypocephalus with verso side, Petri museum. The recto side is divided into three registers. The middle one depicts two adoring baboons flanking the four ram headed - god. The third register depicts the bark of Thot and most probably the solar boat. ${ }^{58}$

\section{Doc. 20 Fig. 20}

Linen -Hypocephalus, Petri museum two registers. The upper one depicts eight adoring baboons, while the lower register depicts the owner of hypocephalus Paunhatef delivering mAat sign to Ra rendered as a falcon. ${ }^{59}$

\section{Doc. 21 Fig. 21}

Plastered - Linen of Sri.t xnsw, Zagreb museum with three registers. The first register depicts the Thot's boat with two seated baboons, one inside a shrine and the other is outside. In the second register; are four standing baboons in adoration attitude, and four ram headed - god encircle them. In the third register; is the divine cow followed by two seated gods. ${ }^{60}$

\section{Doc. 22 Fig. 22}

Plastered - Linen Hypocephalus of tA DHwty, Zagreb museum with three registers. It is almost identical to Doc.21, except the representation of three seated gods behind the divine cow instead of two. ${ }^{61}$

\section{Doc. 23 Fig. 23}

Plastered - Linen Hypocephalus of DHwty irdis, Zagreb museum. This is a fragment with two registers. The topmost one probably depicts the four ram headed - god flanked by four baboons in adoration attitude. However, the lower one depicts the cow goddess followed by three seated gods. ${ }^{62}$

\section{Doc. 24 Fig. 24}

Bronze Hypocephalus of Irethorrou, Louvre museum with four registers. It is almost identical to Doc. 1 and Doc.11 with tiny differences. ${ }^{63}$

\section{Doc. 25 Fig. 25}

Hypocephalus of Tatu, Louvre museum with four registers. The first register depicts Amon - Ra with double faces between two boats, one with a scarab and the other with a mummified outstretch wings hawk. The second register depicts the four ram headed - god flanked by eight baboons in adoring position. The third register is occupied by the solar boat of Ra accompanied by six deities and the moon bark with one baboon seated on a shrine facing the lotus plant. The representation of a seated child of the sun - god is between the two boats. The last register includes the deceased soul in a bird form adoring the divine cow, followed by the wdjAt eye, a seated god rendered as Amon, and a standing serpent with human limbs offering wdjAt eye. ${ }^{64}$

\section{Doc. 26 Fig. 26}

Plastered - Linen Hypocephalus of pw-r -m, Museum of Pennsylvania, ${ }^{65}$ with four registers. The right part of the first register is damaged, but the rest represents the double faced - god and a boat with the mummified falcon god. The four ram headed - god is flanked by six adoring baboons. The third register is partly damaged, it represents a child of the sun - god on top of the sky symbol, flanked by the solar boat and the moon bark with different deities. The fourth register includes a scarab, the four sons of Horus, the divine cow, the wdjAt goddess, besides, both the seated human and the snake gods.

\section{Doc. 27 Fig. 27}

Plastered-Linen Hypocephalus, Museum of Pennsylvania with two registers. The first register is mostly damaged. However, the second register includes four standing baboons in adorning attitude. ${ }^{66}$

\section{Doc. 28 Fig. 28}

Plastered-Linen Hypocephalus of T-kr-hb, Firenze museum with three registers. The first one depicts the double faced - god. A boat with a scarab is in the right side, and another with the mummified falcon god is in the left. The second register includes four adoring baboons encircle the four ram headed - god. The third register depicts the divine cow, god with human limbs while offering wdjAt eye to a seated god. ${ }^{67}$

Doc. 29 Fig. 29

Linen Hypocephalus of Synn, Brussels museum with four registers. It is almost identical to Doc. 1 and Doc.11, with tiny differences. ${ }^{68}$ 


\section{Doc. 30 Fig. 30}

Hypocephalus of the Nash Collection with verso side containing the divine cow seated. The recto side has four registers; the first one includes the four ram headed - god. To the right hand side; is a boat with the mummified falcon. In the second register; the sun god is represented seated, and flanked by four adoring baboons, two are preceding, and the others are in behind. On the left; the four sons of Horus are existent. The third register is occupied with two boats; one carries a scarab inside the solar disk and the other carries a ram. The last register represents a seated person on a boat. $^{69}$

\section{Doc. 31 Fig. 31}

Plastered - Linen Hypocephalus of Walters Mayers Collection with two registers. The upper one depicts two baboons adorning the deceased mummy. Moreover, the lower one shows two adoring baboons either. The hypocephalus also occupied by the four sons of Horus; two in each register. ${ }^{70}$

Doc. 32 Fig. 32

Bronze Hypocephalus, Berlin museum with three registers; although, some parts are damaged. It is almost identical to Doc.26, except for the absence of the third register, which is found in Doc.26 and the scarab in the current doc.'s third register. $^{71}$

\section{Doc. 33 Fig. 33}

Bronze Hypocephalus of Dd Hr nb tA iHt wife, Boston museum with four registers. It is almost identical to Doc.1 of $\mathrm{Hr}$ wDA, with tiny differences. Of these, the decreasing of number of gods in the solar boat. ${ }^{72}$

\section{Doc. 34 Fig. 34}

Plastered - Linen Hypocephalus of tA S n xnsw, Ashmolean museum with four registers. It is almost identical to Doc. 2 , with tiny differences. ${ }^{73}$

\section{Doc. 35 Fig. 35}

Hypocephalus of tA S n HApy, Ashmolean museum ${ }^{74}$ with two registers. The upper one includes the four ram headed god, and four seated adoring baboons flank him. The Lower register depicts the divine cow with the deceased's mummy laying on its back.

\section{Doc. 36 Fig. 36}

Bronze Hypocephalus, Torino museum with three registers. ${ }^{75}$ The first register depicts the double faced - god with two boats to the right; the upper includes a shrine confined between the two protective goddesses, and the lower with a scarab confined between a seated baboon and $\mathrm{Ra}$ in one form. The second register depicts the four ram headed - god with two adoring standing baboons to the right. The third register depicts a scarab, a seated deity, a shrine, the four sons of Hours in two rows, the divine cow, wdjAt goddess, and a human seated god with an opposite bird facing the snake deity with human limbs.

\section{Doc. 37 Fig. 37}

Plastered - Linen, Torino museum with four registers. ${ }^{76}$ The first register depicts the double faced - god between two boats, one with a scarab and a baboon while the other with Sokar. The second register includes the four ram headed god, and four adoring baboons flank him. The third register depicts a boat with a seated representation of Ra with the ram head and Hours. In the middle, there is a crouching lion facing a scarab and Nut. The last register depicts the four sons of Horus, the divine cow, and a shrine.

\section{Doc. 38 Fig. 38}

Plastered - Linen, Torino museum with sole register. ${ }^{77}$ This depicts the four ram headed - god with two heads of a ram, besides, two other animals. There are two baboons; one to the right and the other is to the left. Two snakes framed the scene.

\section{Doc. 39 Fig. 39}

Plastered - Linen of ns tA ntrt tn, Torino museum with three registers. The first register depicts the double faced - god between two boats; one with a bird and the other with a standing baboon in adoration attitude before a seated figure personifying Horus - Ra. The second register depicts eight adoring baboons flanking the four ram headed - god. The third register is occupied by a snake with human limbs offering the wdjAt eye to a seated deity, the wdjAt goddess, the divine cow, and then the four sons of Horus in seated form. ${ }^{78}$

\section{Doc. 40 Fig. 40}

Plastered - Linen of $\mathrm{Hr}$ nfr, Torino museum with two registers. ${ }^{79}$ The first register depicts four baboons flanking the four ram headed -god. The second register includes a boat with two seated baboons; one inside a naos and the other is outside in adoring attitude. 


\begin{tabular}{|c|c|c|c|c|c|c|c|c|c|c|c|c|c|c|c|c|c|c|}
\hline \multirow{4}{*}{ Figures } & \multirow{4}{*}{ Registers } & \multirow{4}{*}{$\begin{array}{l}\text { Baboons } \\
\text { total No. }\end{array}$} & \multicolumn{16}{|c|}{ scenes } \\
\hline & & & \multicolumn{4}{|c|}{ Seated headed ram god } & \multicolumn{3}{|c|}{$\begin{array}{l}\text { Thot Boat } \\
\text { (B) }\end{array}$} & \multicolumn{3}{|c|}{$\begin{array}{l}\text { Four sons of god Horus } \\
\text { (C) }\end{array}$} & \multicolumn{3}{|c|}{$\begin{array}{l}\text { Scarab boat } \\
\text { (D) }\end{array}$} & \multicolumn{3}{|c|}{$\begin{array}{l}\text { Offering wDAt eye to } \\
\text { God Min } \\
\text { (E) }\end{array}$} \\
\hline & & & \multirow{2}{*}{$\begin{array}{c}\text { Baboons } \\
\text { No. }\end{array}$} & \multirow{2}{*}{$\begin{array}{l}\text { Reg. } \\
\text { No. }\end{array}$} & \multicolumn{2}{|c|}{ Position } & \multirow{2}{*}{$\begin{array}{l}\text { Reg. } \\
\text { No. }\end{array}$} & \multicolumn{2}{|c|}{ Position } & \multirow{2}{*}{$\begin{array}{l}\text { Reg. } \\
\text { No. }\end{array}$} & \multicolumn{2}{|c|}{ Position } & \multirow{2}{*}{$\begin{array}{l}\text { Reg. } \\
\text { No. }\end{array}$} & \multicolumn{2}{|c|}{ Position } & \multirow{2}{*}{$\begin{array}{l}\text { Reg. } \\
\text { No. }\end{array}$} & \multicolumn{2}{|c|}{ Position } \\
\hline & & & & & Stand. & Sit. & & Stand. & Sit. & & Stand. & Sit. & & Stand. & Sit. & & Stand. & Sit. \\
\hline Fig. 1 & 1234 & 6 & 2 & 2 & $\sqrt{ }$ & - & 3 & - & $\sqrt{ }$ & 4 & $\sqrt{ }$ & - & 1 & - & $\sqrt{1}$ & 4 & - & - \\
\hline Fig. 2 & 1234 & 6 & 2 & 2 & $\sqrt{ }$ & - & 3 & - & $\sqrt{ }$ & 4 & $\sqrt{ }$ & - & 1 & - & $\sqrt{ }$ & 4 & - & - \\
\hline Fig. 3 & 123 & 5 & 4 & 2 & $\sqrt{ }$ & - & - & - & - & 3 & $\sqrt{ }$ & - & 1 & - & - & 3 & \multicolumn{2}{|c|}{ Damaged } \\
\hline Fig. 4 & 1 & 1 & - & - & - & - & - & - & - & 1 & $\sqrt{ }$ & - & - & - & - & - & - & - \\
\hline Fig. 5 & 12 & 3 & 2 & 1 & $\sqrt{ }$ & - & - & - & - & 2 & $\sqrt{ }$ & - & - & - & - & 2 & - & - \\
\hline Fig. 6 & 123 & 3 & 2 & 1 & $\sqrt{ }$ & - & - & - & - & 3 & $\sqrt{ }$ & - & - & - & - & 3 & - & - \\
\hline Fig. 7 & 123 & 7 & 6 & 2 & $\sqrt{ }$ & - & - & - & - & 3 & $\sqrt{ }$ & - & 1 & - & - & 3 & - & - \\
\hline Fig. 8 & 123 & 5 & 4 & 2 & $\sqrt{ }$ & - & - & - & - & 3 & - & $\sqrt{ }$ & 1 & - & - & 3 & - & - \\
\hline Fig. 9 & 1234 & 2 & - & 2 & - & - & 3 & - & $\sqrt{ }$ & - & - & - & - & - & - & - & - & \\
\hline Fig. 10 & 123 & 9 & 8 & 2 & $\sqrt{ }$ & $\sqrt{ }$ & - & - & - & 3 & $\sqrt{ }$ & - & - & - & - & - & - & - \\
\hline Fig. 11 & 1234 & 5 & - & 2 & - & - & 3 & - & $\sqrt{ }$ & 4 & $\sqrt{ }$ & - & 1 & - & $\sqrt{ }$ & 4 & $\sqrt{ }$ & - \\
\hline Fig. 12 & 123 & 4 & 2 & 2 & $\sqrt{ }$ & - & 3 & - & $\sqrt{ }$ & - & - & - & 1 & - & $\sqrt{ }$ & - & - & \\
\hline Fig. 13 & 123 & - & - & 1 & - & - & - & - & - & - & - & - & - & - & - & 2 & - & - \\
\hline Fig. 14 & 123 & 4 & 4 & 2 & $\sqrt{ }$ & - & - & - & - & - & - & - & 1 & - & - & - & - & - \\
\hline Fig. 15 & 1234 & 5 & 2 & 2 & $\sqrt{ }$ & - & 3 & - & $\sqrt{ }$ & 4 & $\sqrt{ }$ & - & 1 & - & - & 4 & - & - \\
\hline Fig. 16 & 12 & - & - & 2 & - & - & - & - & - & - & - & - & 1 & - & - & - & - & - \\
\hline Fig. 17 & 12 & - & - & - & - & - & - & - & - & - & - & - & - & - & - & - & - & - \\
\hline Fig. 18 & 123 & 2 & 2 & 2 & $\sqrt{ }$ & - & - & - & - & - & - & - & - & - & - & 3 & - & - \\
\hline Fig. 19 & 123 & 3 & 2 & 2 & $\sqrt{ }$ & - & 1 & - & $\sqrt{ }$ & - & - & - & - & - & - & & Not Clea & \\
\hline Fig. 20 & 12 & 8 & - & - & - & - & - & - & - & - & - & - & - & - & - & - & - & - \\
\hline
\end{tabular}




\begin{tabular}{|c|c|c|c|c|c|c|c|c|c|c|c|c|c|c|c|c|c|c|}
\hline \multirow{4}{*}{ Figures } & \multirow{4}{*}{ Registers } & \multirow{4}{*}{$\begin{array}{l}\text { Baboons } \\
\text { total No. }\end{array}$} & \multicolumn{16}{|c|}{ scenes } \\
\hline & & & \multicolumn{4}{|c|}{ Seated headed ram god } & \multicolumn{3}{|c|}{$\begin{array}{c}\text { Thot Boat } \\
\text { (B) }\end{array}$} & \multicolumn{3}{|c|}{ Four sons of god } & \multicolumn{3}{|c|}{ Scarab boat } & \multicolumn{3}{|c|}{$\begin{array}{l}\text { Offering wDAt eye to God } \\
\text { Min } \\
\text { (E) }\end{array}$} \\
\hline & & & \multirow{2}{*}{$\begin{array}{c}\text { Baboons } \\
\text { No. }\end{array}$} & \multirow{2}{*}{$\begin{array}{l}\text { Reg. } \\
\text { No. }\end{array}$} & \multicolumn{2}{|c|}{ Position } & \multirow{2}{*}{$\begin{array}{l}\text { Reg. } \\
\text { No. }\end{array}$} & \multicolumn{2}{|c|}{ Position } & \multirow{2}{*}{$\begin{array}{l}\text { Reg. } \\
\text { No. }\end{array}$} & \multicolumn{2}{|c|}{ Position } & \multirow{2}{*}{$\begin{array}{l}\text { Reg. } \\
\text { No. }\end{array}$} & \multicolumn{2}{|c|}{ Position } & \multirow{2}{*}{$\begin{array}{l}\text { Reg. } \\
\text { No. }\end{array}$} & \multicolumn{2}{|c|}{ Position } \\
\hline & & & & & Stand. & Sit. & & Stand. & Sit. & & Stand. & Sit. & & Stand. & Sit. & & Stand. & Sit. \\
\hline Fig. 21 & 123 & 7 & 4 & 2 & $\sqrt{ }$ & - & 1 & - & $\sqrt{ }$ & 3 & - & $\sqrt{ }$ & - & - & - & - & - & - \\
\hline Fig. 22 & 123 & 7 & 4 & 2 & $\sqrt{ }$ & - & 1 & - & $\sqrt{ }$ & 3 & - & $\sqrt{ }$ & - & - & - & - & - & - \\
\hline Fig. 23 & 12 & 5 & 4 & 1 & $\sqrt{ }$ & - & - & - & - & 2 & - & $\sqrt{ }$ & - & - & - & - & - & - \\
\hline Fig. 24 & 1234 & 6 & 2 & 2 & $\sqrt{ }$ & - & 3 & - & $\sqrt{ }$ & 4 & $\sqrt{ }$ & - & 1 & - & $\sqrt{ }$ & 4 & - & - \\
\hline Fig. 25 & 1234 & 9 & 8 & 2 & $\sqrt{ }$ & - & 3 & - & $\sqrt{ }$ & - & - & - & 1 & - & - & 4 & - & - \\
\hline Fig. 26 & 1234 & 8 & 6 & 2 & $\sqrt{ }$ & - & 3 & - & $\sqrt{ }$ & 4 & $\sqrt{ }$ & - & 1 & \multicolumn{2}{|c|}{ Damaged } & 4 & - & - \\
\hline Fig. 27 & 12 & 4 & 4 & 2 & $\sqrt{ }$ & - & - & - & - & - & - & - & - & - & - & - & - & - \\
\hline Fig. 28 & 123 & 4 & 4 & 2 & $\sqrt{ }$ & - & - & - & - & - & - & - & 1 & - & - & 3 & - & - \\
\hline Fig. 29 & 1234 & 6 & 2 & 2 & $\sqrt{ }$ & - & 3 & - & $\sqrt{ }$ & 4 & $\sqrt{ }$ & - & 1 & - & $\sqrt{ }$ & 4 & - & - \\
\hline Fig. 30 & 1234 & 5 & - & 1 & - & - & - & - & - & 2 & $\sqrt{ }$ & - & 3 & - & - & - & - & - \\
\hline Fig. 31 & 12 & 4 & - & - & - & - & - & - & - & 1,2 & $\sqrt{ }$ & - & - & - & - & - & - & - \\
\hline Fig. 32 & 123 & 8 & 6 & 2 & $\sqrt{ }$ & - & 1 & - & $\sqrt{ }$ & 3 & $\sqrt{ }$ & - & - & - & - & 3 & - & - \\
\hline Fig. 33 & 1234 & 2 & 2 & 2 & $\sqrt{ }$ & - & 3 & - & $\sqrt{ }$ & 4 & $\sqrt{ }$ & - & 1 & - & $\sqrt{ }$ & - & - & - \\
\hline Fig. 34 & 1234 & 6 & 2 & 2 & $\sqrt{ }$ & - & 3 & - & $\sqrt{ }$ & 4 & $\sqrt{ }$ & - & 1 & - & - & 4 & - & - \\
\hline Fig. 35 & 12 & 8 & 8 & 1 & $\sqrt{ }$ & - & - & - & - & - & - & - & - & - & - & - & - & - \\
\hline Fig. 36 & 123 & 4 & 2 & 2 & $\sqrt{ }$ & - & - & - & - & 3 & $\sqrt{ }$ & - & 1 & - & $\sqrt{ }$ & 3 & - & - \\
\hline Fig. 37 & 1234 & 6 & 4 & 2 & $\sqrt{ }$ & - & - & - & - & 4 & $\sqrt{ }$ & - & 1 & - & $\sqrt{ }$ & - & - & - \\
\hline Fig. 38 & 1 & 1 & 1 & 1 & $\sqrt{ }$ & - & - & - & - & - & - & - & - & - & - & - & - & - \\
\hline Fig. 39 & 123 & 10 & 8 & 2 & $\sqrt{ }$ & - & 1 & $\sqrt{ }$ & - & 3 & - & $\sqrt{ }$ & - & - & - & 3 & - & - \\
\hline Fig. 40 & 12 & 5 & 4 & 1 & $\sqrt{ }$ & - & 2 & - & $\sqrt{ }$ & - & - & - & - & - & - & - & - & - \\
\hline
\end{tabular}




\section{Results}

Table (3)

Table (2)

\begin{tabular}{|c|c|}
\hline \multicolumn{2}{|c|}{ Registers No. } \\
\hline Registers No. & Hypocephli \\
\hline 1 & 2 \\
\hline 2 & 6 \\
\hline 3 & 15 \\
\hline 4 & 13 \\
\hline Incompelete & 4 \\
\hline & 40 \\
\hline
\end{tabular}

Table (4)

\begin{tabular}{|c|c|}
\hline \multicolumn{2}{|c|}{$\begin{array}{c}\text { Baboons No. with the seated ram headed } \\
\text { God }\end{array}$} \\
\hline Baboons No. & Hypocephli \\
\hline- & 9 \\
\hline 1 & 1 \\
\hline 2 & 13 \\
\hline 4 & 9 \\
\hline 6 & 3 \\
\hline 8 & 4 \\
\hline Incompelete & 1 \\
\hline & 40 \\
\hline
\end{tabular}

Table (6)

\begin{tabular}{|c|c|}
\hline \multicolumn{2}{|c|}{ Baboons position in Thot boat } \\
\hline Position & Hypocephli \\
\hline Scene not represented & 18 \\
\hline Standing & 1 \\
\hline Sitting & 17 \\
\hline Incompelete & 4 \\
\hline & 40 \\
\hline
\end{tabular}

Table (8)

\begin{tabular}{|c|c|}
\hline \multicolumn{2}{|c|}{ Baboons position in the Scarab boat } \\
\hline Position & Hypocephli \\
\hline- & 10 \\
\hline Scene not represented & 16 \\
\hline Standing & 0 \\
\hline Sitting & 9 \\
\hline Incompelete & 5 \\
\hline & 40 \\
\hline
\end{tabular}

\begin{tabular}{|c|c|}
\hline \multicolumn{2}{|c|}{ Baboons Total No. } \\
\hline Baboons No. & Hypocephli \\
\hline- & 3 \\
\hline 1 & 2 \\
\hline 2 & 3 \\
\hline 3 & 1 \\
\hline 4 & 5 \\
\hline 5 & 6 \\
\hline 6 & 6 \\
\hline 7 & 3 \\
\hline 8 & 4 \\
\hline 9 & 2 \\
\hline 10 & 1 \\
\hline Incompelete & 4 \\
\hline & 40 \\
\hline
\end{tabular}

Table (5)

\begin{tabular}{|c|c|}
\hline $\begin{array}{c}\text { Baboons position with the four ram } \\
\text { headed God }\end{array}$ \\
\hline Position & Hypocephli \\
\hline- & 9 \\
\hline Standing & 29 \\
\hline Sitting & 0 \\
\hline Standing \& Sitting & 1 \\
\hline Incompelete & 1 \\
\hline & 40 \\
\hline
\end{tabular}

Table (7)

\begin{tabular}{|c|c|}
\hline $\begin{array}{c}\text { Baboons position in the scene of four sons of } \\
\text { God Horus }\end{array}$ \\
\hline Position & Hypocephli \\
\hline Scene not represented & 14 \\
\hline Standing & 20 \\
\hline Sitting & 5 \\
\hline Incompelete & 1 \\
\hline & 40 \\
\hline
\end{tabular}

Table (9)

\begin{tabular}{|c|c|}
\hline $\begin{array}{c}\text { Baboons position in the scene of offering wDAt } \\
\text { eye to God Min }\end{array}$ \\
\hline Position & Hypocephli \\
\hline- & 19 \\
\hline Scene not represented & 18 \\
\hline Standing & 1 \\
\hline Sitting & 0 \\
\hline Incompelete & 2 \\
\hline & 40 \\
\hline
\end{tabular}

Current study results are concluded into 8 tables (tables 2-9), as follows: 


\section{Table (2)}

Indicate the most common form was the three registers' hypocephali, which is existent in 15 hypocephali out of 40 with $37.5 \%$. As well as ones with four registers were existent in 13 hypocephali with $32.5 \%$. On the other hand, very few hypocephali are shown with 1 register, equals $5 \%$, and ones with double registers reaches $15 \%$.

\section{Table (3)}

It is noticeable, the total number of baboons varies between 1 and 10.The most common number of baboons is fluctuated between 4 -with 12.5\%-, 5 and 6 with 15\% for each. Exceptionally; 3 or 10 baboons are depicted one time on hypocephalus with $2.5 \%$. The frequency average of Hypocephali with 2 or 7 baboons was $7.5 \%$. The same average refers to hypocephli free from baboons. However, Hypocephali with 1 or 9 baboons represent 5\%. Table (3) points out four hypocephli with 8 baboons; these indicate $10 \%$. Finally, despite the different numbers of baboons on hypocephali; there is no perceivable distinction in their occurrence percentages in the hypocephli.

\section{Table (4)}

There are 13 hypocephli with $32.5 \%$ showing the seated ram headed God flanked by 2 baboons. However; scenes with 4 baboon or even free of represent $22.5 \%$. It is noticed, a sole hyocephlus is registered to have a single baboon around the seated ram headed God.

\section{Table (5)}

It is noticeable, the standing baboons with the four ram headed God is the most common position, represented in 29 hypocephli with $72 \%$ average. In the Contrary, the seated position represents $0 \%$.

\section{Table (6)}

It is noticeable, the seated position of baboons in Thot boat is the most common, it occurred in 17 hypocephli, which equals $42.5 \%$. On the other hand, a sole hypocephlus represents the baboons in standing position, shaping $2.5 \%$. It is important to mention, the scenes of Thot boat with baboons were not occurred in about 18 hypocephli, and shaping $45 \%$ in infrequency average. This was the highest percentage in the table.

\section{Table (7)}

This table points out the baboons in standing position in the four sons of God Horus was the most common position; shaping 50\%, while seated baboons frequented with $12.5 \%$. However; 14 hypocephli shaping $35 \%$ are free from the scene of four sons of God Horus.

\section{Table (8)}

This table shows 9 hypocephli with $22.5 \%$ representing seated baboons in the scene of Scarab boat in comparison to standing baboons, which did not appear in any hypocephlus. There are 10 hypocephli shaping $25 \%$ with no baboons, as well as 16 hypocephli shaping $40 \%$ are free from the scene itself.

\section{Table (9)}

According to this table; baboons' appearance in the scene of offering wDAt eye to God Min can be neglected. Baboons are not existent in 19 hypocephli shaping $47.5 \%$ in infrequency average, and the scene itself is not existent in 18 hypocephli shaping $45 \%$. A sole hypocephlus includes a standing baboon shaping $2.5 \%$. On the other hand, seated baboons are neither depicted.

\section{Discussion}

This research deals with 40 Late Periods hypocephali of different religious and mysterious scenes. All the scenes are depicted to preserve warmness of the head, as well as, the mummy of the deceased to ensure his resurrection and rebirth in the netherworld. The five baboons' scenes -A, B, C, D, E as represented in Table 1- are the most prominent ones.

Scene (A) is the central one in all hypocephali. It includes a seated deity with four ram's heads in the majority of the hypocephali representing the world (In few cases with two). This god refers to either god Amon Ra or god Khnum as the creator god. ${ }^{80}$ It also indicates to the spiritual force of god Ra. ${ }^{81}$ This seated position of the god in the middle refers to the primeval creation's power. ${ }^{82}$ Other opinions stated; this seated god most probably represented god Atum, the four spirits (Ra, Shu, Geb and Osiris), Winds, or the four corners of the world. ${ }^{83}$ On each side of the seated god; there are standing baboons (In very few cases are seated) with lunar disk and crescent over their heads or without. They are shown with upraised hands adoring the god referring to god Thot, who is shown before Ra as a sign of night sun. ${ }^{84}$ They are varying in numbers from two to eight. Each number has a religious symbolism like the duality of two, the plurality of three, the completeness, eternity and totality of four as well as the double of completeness of eight. ${ }^{85}$

Scene (B) represents two seated baboons, where the two celestial boats of the sun and the moon are represented. The moon boat (Thot Boat) includes two baboons. One of them is sitting inside a shrine as a symbol of the god Ra, and the other is in an adoring attitude outside the shrine as a symbol of the god Thot; holding in some cases wdjAt eye as a 
sign of light, protection, and all good things. So, baboon as a sacred animal of god Thot has the religious symbolism of both gods of the sun and the moon, as a best example of the ancient Egyptian syncretism. ${ }^{86}$

Scene (C) represents the four sons of god Horus standing in mummified form while, the others are seated (In very few hypocephali). These were the guardian gods of the internal viscera of the deceased mummy. One of them called Hapy; represented with a baboon head. These four gods resemble the four winds or the four cardinal points. ${ }^{87}$

Scene (D) represents the boat; including a seated baboon in adoration attitude before the sun god Ra, but mainly to a scarab, which the ancient Egyptians worshipped taking the name xpr, referring to" he who came into being". 88

Scene (E) shows god Min seated, and god Nehenkaw who is mentioned in chapter 125 as one of the judges of the dead in different forms, such as a serpent with human limbs, a serpent with a hawk head, and a standing baboon presenting him the wdjAt eye. ${ }^{89}$

\section{Benefits of this Research in Tourist Guidance}

- It introduces a very important religious issue; this is Hypocephalus in Ancient Egyptian Religion, which is a unique amulet for the time being.

- At the request of the General Tourist Guides syndicate, this paper aims to increase the religious issues; and involve it within future research plans in the Tourism Guidance departments at the Faculties of Tourism and Hotels.

- Accordingly, tourist guides can be provided with academic information to help explaining some of the mysterious religious scenes; depicted on Hypocephali as one of the most important Late Periods miniature art.

\section{Conclusion}

Amulets were an essential adornment worn by Ancient Egyptians of all social classes; whether during lifetime or in the afterlife. These amulets took several shapes; of these, animals, sacred objects, hieroglyphic symbols, and small round disk-shaped object called (Hypocephalus). The chief purpose of amulets was to bestowing magical protection to the deceased, and provide him with power. Ancient Egyptians believed in resurrection, so hypocephalus was one of the chief Late Periods amulets, used to achieve this purpose. The Ancient Egyptians were very keen to depict very mysterious and complete scenes on hypocephalus to achieve the meant purpose. In many instances; exact meaning of some symbols cannot be recognized. In other words, hypocephali' scenes are characterized by syncretism in art. According to Ali Radwan, Ancient Egyptians intended them very complicated and mysterious to achieve its target. ${ }^{90}$ 


\section{Table 10: Hypocephali}

\begin{tabular}{|c|c|c|c|c|c|c|c|c|c|}
\hline Figures & Museum & Number & Period & Material & $\begin{array}{c}\text { Place of } \\
\text { Discovery }\end{array}$ & Owner's Name & Condition & Dimensions & $\begin{array}{l}\text { Verso } \\
\text { side }\end{array}$ \\
\hline Fig. 1 & British & 37.330 & Late & Bronze & Abydos & $\mathrm{wDA}$ & Fair & - & - \\
\hline Fig. 2 & British & EA 8445-BS 8445 & Late & Plastered-Linen & - & - & Fair & D. $14 \mathrm{~cm}$ & - \\
\hline Fig. 3 & British & EA $36188-B S 8445 \mathrm{e}$ & $26^{\text {th }}-30^{\text {th }}$ Dy. & Plastered-Linen & Thebes & Neshorpakhered & $\begin{array}{l}\text { Fair } \\
\text { (incomplete) }\end{array}$ & D. $14 \mathrm{~cm}$ & - \\
\hline Fig. 4 & British & EA 37907-BS 8445a & Late & Plastered-Linen & - & - & Fair & D. $11.5 \mathrm{~cm}$ & - \\
\hline Fig. 5 & British & EA $37908-B S 8445 f$ & Late & Plastered-Linen & & Hsy $x b$ & $\begin{array}{l}\text { Fair } \\
\text { (incomplete) }\end{array}$ & D. $16.3 \mathrm{~cm}$ & - \\
\hline Fig. 6 & British & EA 74908 & Late & Plastered-papyrus & - & - & $\begin{array}{l}\text { Fair } \\
\text { (incomplete) }\end{array}$ & $\begin{array}{l}\text { L. } 11.5-\mathrm{W} . \\
11 \mathrm{~cm}\end{array}$ & \\
\hline Fig. 7 & British & EA $35875-B S 8445 c$ & Late & Plastered- Linen & - & - & $\begin{array}{l}\text { Fair } \\
\text { (incomplete) }\end{array}$ & D. $21.2 \mathrm{~cm}$ & - \\
\hline Fig. 8 & British & EA 37095-BS 8445a & Late & Plastered- papyrus & - & - & Two Fragments & $\begin{array}{l}\text { L. } 13.1-W . \\
7.5 \mathrm{~cm}\end{array}$ & - \\
\hline Fig. 9 & British & $8445 a$ & Late & Plastered- papyrus & - & - & Fragments & - & - \\
\hline Fig. 10 & British & EA 8446-BS 8446 & Late & Plastered-Linen & - & Hr nt it.f & Good & D. $15.3 \mathrm{~cm}$ & - \\
\hline Fig. 11 & Egyptian & $\begin{array}{l}\text { SR 4/10691/0- JE } \\
38355\end{array}$ & Late & Bronze & Abydos & $\mathrm{Dd} \mathrm{Hr}$ & Good & D. 19 & - \\
\hline Fig. 12 & Egyptian & $\begin{array}{l}\text { SR 4/10686/0-JE } \\
30616-C G ~ 9444\end{array}$ & Late & Plastered - Linen & - & - & Fair & D. 17 & Verso \\
\hline Fig. 13 & Egyptian & $\begin{array}{lr}\mathrm{SR} 4 / 10687 / 0- & \mathrm{JE} \\
\text { 29521- CG 9446 } & \end{array}$ & Late & Plastered - Linen & - & - & Fair & D. $14.5 \mathrm{~cm}$ & - \\
\hline Fig. 14 & Egyptian & $\begin{array}{l}\mathrm{SR} \quad 4 / 10688 / 0-\mathrm{JE} \\
29520-\mathrm{CG} 9445\end{array}$ & Late & Plastered - Linen & - & - & $\begin{array}{l}\text { Fair } \\
\text { (incomplete) }\end{array}$ & D. $14 \mathrm{~cm}$ & - \\
\hline Fig. 15 & Egyptian & $\begin{array}{l}\mathrm{SR} \quad 4 / 10700 / 0-\mathrm{JE} \\
25783-\mathrm{CG} 9448\end{array}$ & Late & Plastered - Linen & - & - & $\mathrm{Bad}$ & D. $23 \mathrm{~cm}$ & - \\
\hline Fig. 16 & $\begin{array}{l}\text { Egyptian } \\
\text { Now in } \\
\text { Sohag } \\
\text { Musum } \\
\text { since 2008 }\end{array}$ & $\begin{array}{l}\text { SR } 4 / 10699 / 0-J E \\
30615-C G 9443\end{array}$ & Late & Plastered- Linen & Akhmim & - & Good & D. $20 \mathrm{~cm}$ & - \\
\hline
\end{tabular}




\begin{tabular}{|c|c|c|c|c|c|c|c|c|c|c|c|}
\hline Fig. 17 & Egyptian & $\begin{array}{l}\mathrm{SR} \quad 4 / 10685 / 0-\mathrm{JE} \\
29768-\mathrm{CG} 9447\end{array}$ & Late & Plastered - Linen & - & & - & & Very good & D. $14.2 \mathrm{~cm}$ & - \\
\hline Fig. 18 & Petrie & UC 16407 & Late & Linen & Abydos & & - & & $\begin{array}{l}\text { Fair } \\
\text { (incomplete) }\end{array}$ & D. $18.4 \mathrm{~cm}$ & Verso \\
\hline Fig. 19 & Petrie & UC 16408 & Late & Plastered- Linen & - & & - & & $\begin{array}{l}\text { Bad } \\
\text { (incomplete) }\end{array}$ & D. $17.5 \mathrm{~cm}$ & Verso \\
\hline Fig. 20 & Petrie & UC 16409 & $30^{\text {th }}$ Dy. & Linen & Abydos & $\begin{array}{l}\mathrm{p} \\
\text { HAt. } \mathrm{f}\end{array}$ & $f$ & Awn & $\begin{array}{l}\text { Fair } \\
\text { (incomplete) }\end{array}$ & D. $8.3 \mathrm{~cm}$ & - \\
\hline Fig. 21 & Zagreb & $\begin{array}{l}\text { Inv. 596-1 - Saleh } \\
\text { M. } 889\end{array}$ & Late & Plastered- Linen & Thebes & Sri.t & t $x \mathrm{n}$ & sw & $\begin{array}{l}\text { Fair } \\
\text { (incomplete) }\end{array}$ & D. $14.5 \mathrm{~cm}$ & - \\
\hline Fig. 22 & Zagreb & $\begin{array}{l}\text { Inv. 596-2 - Saleh } \\
\text { M. } 890\end{array}$ & Late & Plastered- Linen & Thebes & tA $\mathrm{DH}$ & buty & & $\begin{array}{l}\text { Fair } \\
\text { (incomplete) }\end{array}$ & D. $14 \mathrm{~cm}$ & - \\
\hline Fig. 23 & Zagreb & $\begin{array}{l}\text { Inv. 596-3 - Saleh } \\
\text { M. } 891\end{array}$ & Late & Plastered- Linen & Thebes & $\begin{array}{l}\text { DHwty } \\
\text { irdis }\end{array}$ & & & Fragment & $\begin{array}{l}\text { L. } 12.8- \\
\text { W. } 6.5 \mathrm{~cm}\end{array}$ & - \\
\hline Fig. 24 & Louvre & N 3526 & $30^{\text {th }}$ Dy. & Bronze & - & Irethor & orrou & & Good & D. $14.6 \mathrm{~cm}$ & - \\
\hline Fig. 25 & Louvre & - & Late & - & - & Tatu & & & - & - & - \\
\hline Fig. 26 & Penn. & $29-86-436$ & Late & Plastered - Linen & $\begin{array}{l}\text { Dra Abu } \\
\text { El- Naga }\end{array}$ & $\mathrm{pw}-\mathrm{r}-$ & $c-m$ & & $\begin{array}{l}\text { Fair } \\
\text { (incomplete) }\end{array}$ & D. $15.6 \mathrm{~cm}$ & - \\
\hline Fig. 27 & Penn. & $29-87-613$ & Late & Plastered- Linen & $\begin{array}{l}\text { Dra Abu } \\
\text { El-Naga }\end{array}$ & & - & & $\begin{array}{l}\text { Bad } \\
\text { (incomplete) }\end{array}$ & - & - \\
\hline Fig. 28 & Firenze & $5704(=5714)$ & Late & Plastered- Linen & - & $t-k r-$ & $=-h b$ & & Fair & D. $14.4 \mathrm{~cm}$ & - \\
\hline Fig. 29 & Brussels & $\begin{array}{l}\text { E } 6319 \quad(\text { Meux } \\
\text { collection . 35) }\end{array}$ & Late & Linen & - & Synn & & & Good & D. $11 \mathrm{~cm}$ & - \\
\hline Fig. 30 & $\begin{array}{l}\text { Nash } \\
\text { Collection }\end{array}$ & - & Late & - & - & & - & & - & - & Verso \\
\hline Fig. 31 & $\begin{array}{l}\text { Walter } \\
\text { Mayers } \\
\text { Collection }\end{array}$ & - & Very Late & Plastered- Linen & - & & - & & $\begin{array}{l}\text { Fair } \\
\text { (incomplete) }\end{array}$ & - & - \\
\hline Fig. 32 & Berlin & 7792 & Late & Bronze & - & & - & & $\begin{array}{l}\text { Fair } \\
\text { (incomplete) }\end{array}$ & - & - \\
\hline Fig. 33 & Boston & 02.766 & Late & Bronze & Abydos & $\begin{array}{l}\text { Wife } \\
\text { Hr } \\
\text { iHt }\end{array}$ & $\begin{array}{l}\text { of } \\
n b\end{array}$ & $\begin{array}{l}\text { Dd } \\
t A\end{array}$ & Good & - & - \\
\hline Fig. 34 & Ashmolean & AN 1982.1095 & $26^{\text {th }} \mathrm{Dy}$ & Plastered - Linen & - & $t A$ & S & $\mathrm{n}$ & Good & - & - \\
\hline
\end{tabular}




\begin{tabular}{|c|c|c|c|}
\hline Fig. 35 & Ashmolean & - & Late \\
\hline Fig. 36 & Torino & $\begin{array}{l}\text { Inv. 2319-RCGE } \\
\text { 16353- RA code } 1- \\
00000738\end{array}$ & Late \\
\hline Fig. 37 & Torino & $\begin{array}{l}\text { Inv. 2323-RCGE } \\
\text { 16349-RA code 1- } \\
00000736\end{array}$ & Late \\
\hline Fig. 38 & Torino & $\begin{array}{l}\text { Inv. 2326-RCGE } \\
\text { 16346-RA code 1- } \\
00000737\end{array}$ & Late \\
\hline Fig. 39 & Torino & $\begin{array}{l}\text { Inv. 2324-RCGE } \\
\text { 16348-RA code } 1- \\
\text { 00000709 }\end{array}$ & Late \\
\hline Fig. 40 & Torino & $\begin{array}{l}\text { Inv. 2325-RCGE } \\
\text { 16347-RA code 1- } \\
00000710\end{array}$ & Late \\
\hline
\end{tabular}

\begin{tabular}{|c|c|c|c|c|c|}
\hline - & - & $\begin{array}{l}\text { xnsw } \\
\text { tA } \\
\text { HApy }\end{array}$ & $\mathrm{n}$ & $\begin{array}{l}\text { Fair } \\
\text { (incomplete) }\end{array}$ & - \\
\hline Bronze & - & - & & Fair & D. $18.5 \mathrm{~cm}$ \\
\hline Plastered - Linen & - & - & & $\begin{array}{l}\text { Good } \\
\text { (incomplete) }\end{array}$ & D. $23 \mathrm{~cm}$ \\
\hline Plastered - Linen & - & - & & $\begin{array}{l}\text { Fair } \\
\text { (incomplete) }\end{array}$ & D. $14 \mathrm{~cm}$ \\
\hline Plastered - Linen & - & $\begin{array}{l}\text { ns } t A \\
\text { tn }\end{array}$ & ntrt & $\begin{array}{l}\text { Fair } \\
\text { (incomplete) }\end{array}$ & D. $14 \mathrm{~cm}$ \\
\hline Plastered - Linen & - & Hr nfr & & $\begin{array}{l}\text { Bad } \\
\text { (incomplete) }\end{array}$ & D. $15.5 \mathrm{~cm}$ \\
\hline
\end{tabular}




\section{According to the Hypocephali (Case Study) in Table 1, it can be noticed;}

- Ten hypocephali are in exhibition in the British Museum, six are in the Egyptian Museum, and five are in Torino Museum. Petri Museum and Zagreb Museum each encompass three hypocephali. Louvre Museum, Pennsylvania Museum, and Ashmolean Museum; each have two hypocephali. Berlin Museum, Boston Museum, Firenze Museum, Brussels, Sohag Museum, Nash Collection, and Walter Mayers Collection; each encompass a hypocephalus.

- There are thirty-one hypocephali out of forty are made of linen, six of bronze, and three ones are of papyrus, indicating to linen the prominent material of making such amulet in ancient Egypt.

- The majority of hypocephali are in a fair condition helps in studying this odd round disk to get the desired results.

- All the hypocephali's diameter vary from 11 to $23 \mathrm{~cm}$.

- All the hypocephali have one side (Recto), except for Figs. 12, 18, 19 and 30; each one is double sides (Recto and Verso).

\section{Figures}

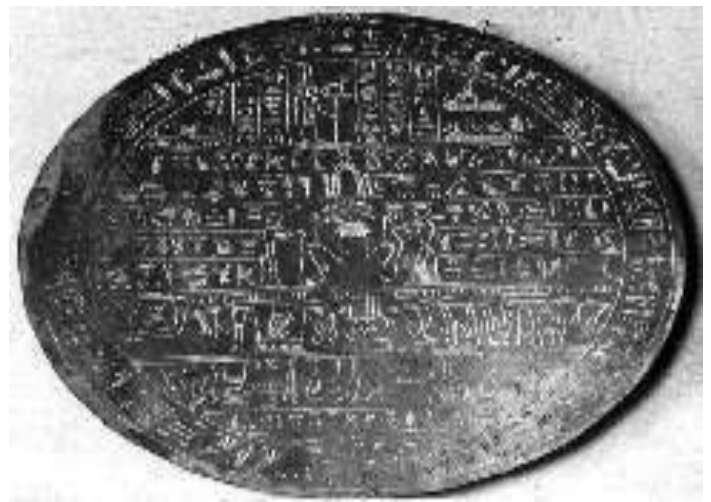

Figure (1)

مفيدة حسن الوشاحى(991 (1)), الفنون في عصر الصحوة الأخيرة للحضـارة

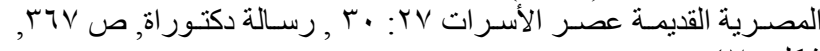
شvن شvن

Petrie, W. M. (1902), Abydos I, London, pp. 49-51, pl. LXXVII, LXXIX Fig. 3.

http://www.britishmuseum.org/research/collect ion_online/collection_object_details/collection _image_gallery.aspx?assetId=232557\&objectI $\bar{d}=117698 \&$ partId $=1 \quad$ (Last Accessed 27/1/2015)

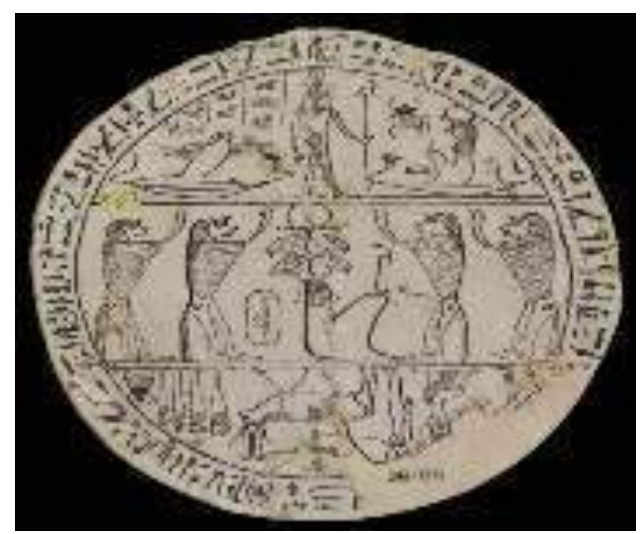

Figure (3)

Birch, S. (1884), P S B A 6, London, pp. 129-131.

Wilkinson, R. H. (1994), symbol and magic in Egyptian Art, London, pp. 72, 73, Fig. 45.

Pinch, G. (1994), Magic in Ancient Egypt, London, fig.85.

Shaw, I. and P. Nicholson (2002) The British

Museum of Ancient Egypt, Cairo, pp. 137, 138.

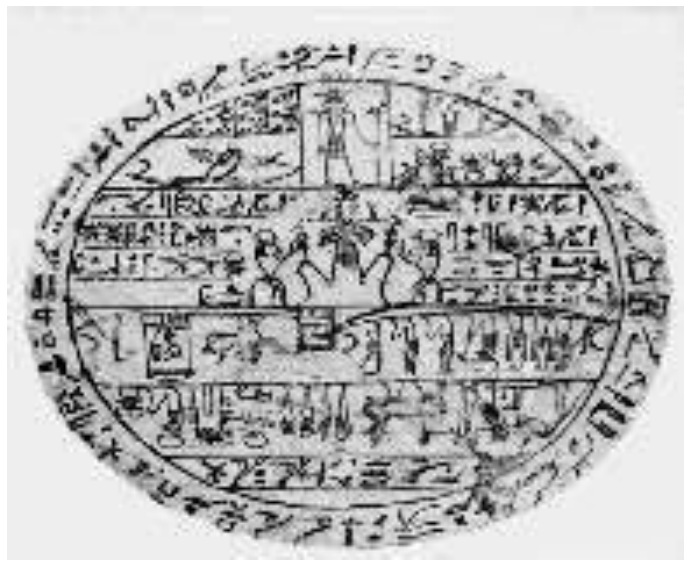

Figure (2)

Porter, B. and R. Moss (1964), Vol.1, P.2, London, p. 845.

Birch, S. (1884), P S B A 6, London, p. 185-187, Fig after p. 186.

Birch, S. (1885), P S B A 7, London, pl. without no.

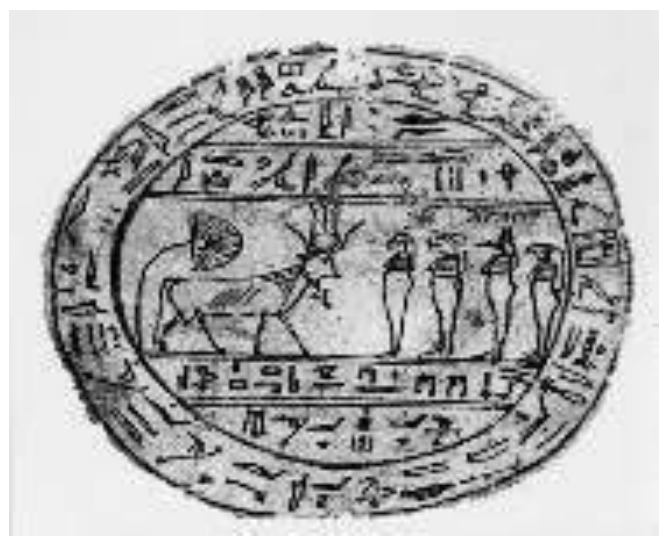

Figure (4)

Birch, S. (1884), P S B A 6, London, pp. 129 131 


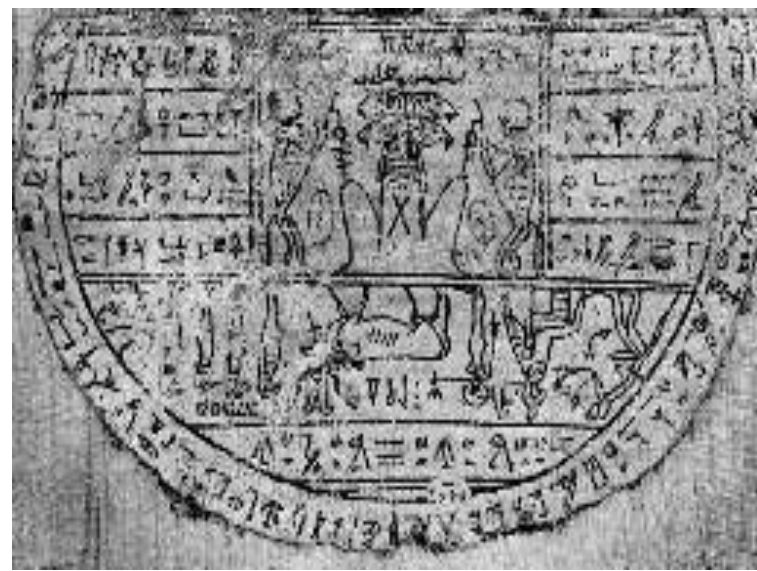

Figure (5)

Birch, S. (1885), P S B A 7, London, pl. without no. Birch, S. (1884), P S B A 6, London, pp. 185-187.

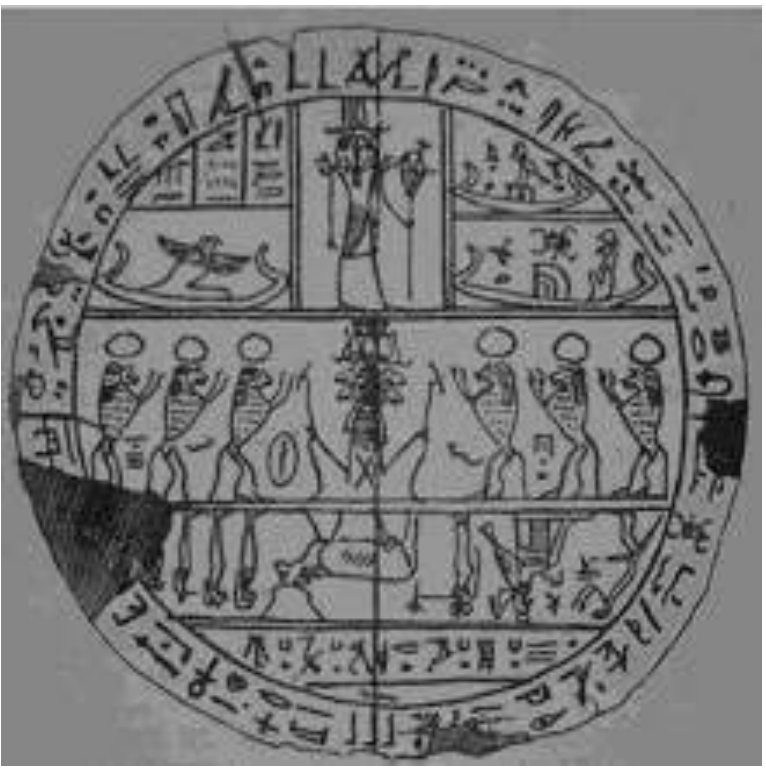

Figure (7)

Wiedemann, A. (1897), Religion of the Ancient Egyptians, London, p. 298, Fig. 72.

Birch, S. (1884), P S B A 6, London, pl. with no number.

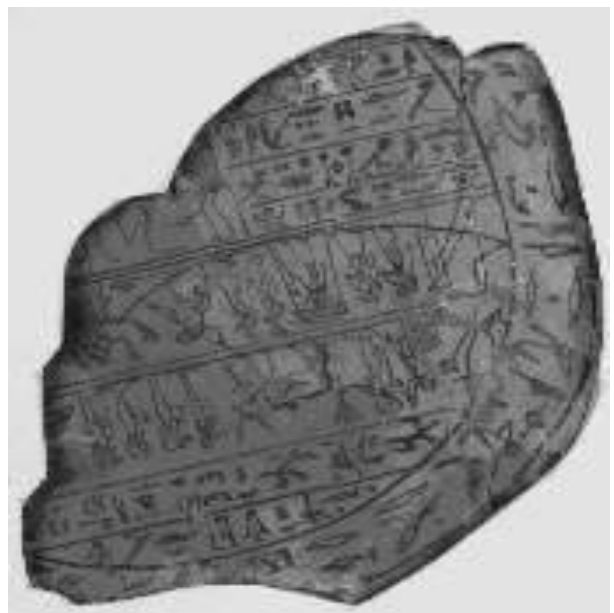

Figure (6)

http://www.britishmuseum.org/research/collection _online/collection_object_details.aspx?objectId=1 23478\&partId=1\&searchText=Hypocephalus $+\& i$ mages $=$ true $\&$ page $=1($ Last Accessed 27/1/2015)

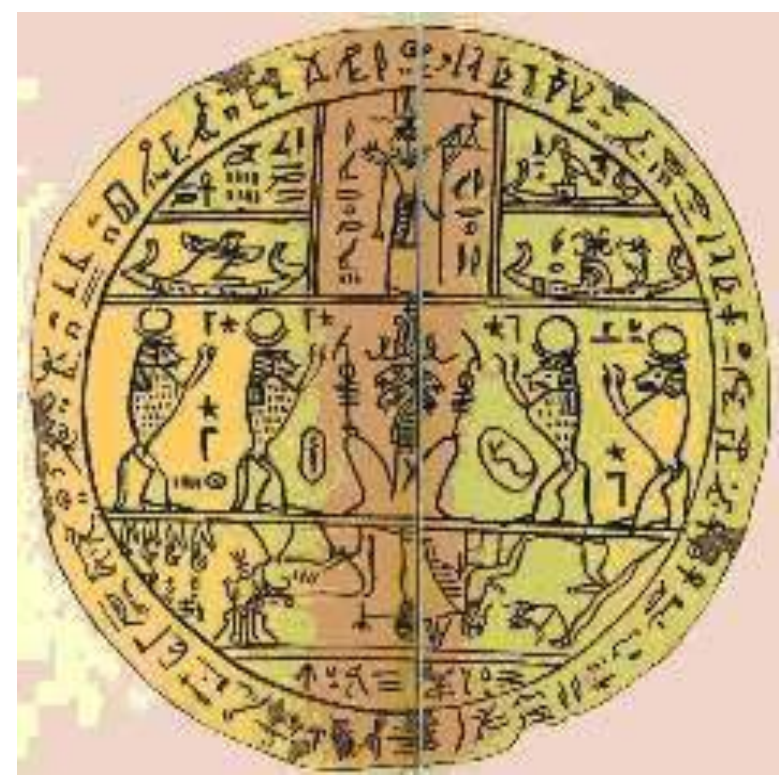

Figure (8)

Birch, S. (1884), P S B A 6, London, p. 106-107, 129131. 


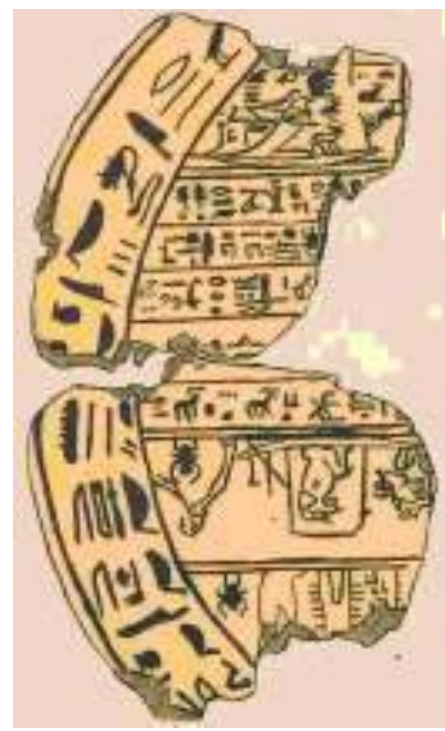

Figure (9)

Birch, S. (1885), P S B A 7, London, pl. without No.

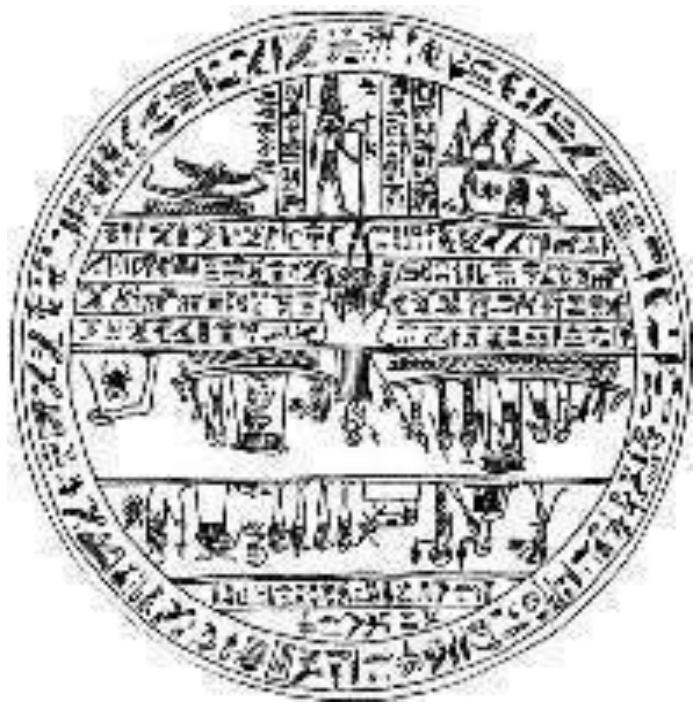

Figure (11)

Egyptian Museum SR, JE.

مفيدة حسن الوشـاحى(1991), الفنون فى عصـر الصحوة الأخيرة

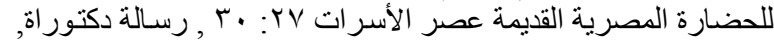
ص ص ז

Petrie, W. M. (1902), Abydos I, London, pp. 49-51, pl. LXXVI, LXXIX Fig. 5.

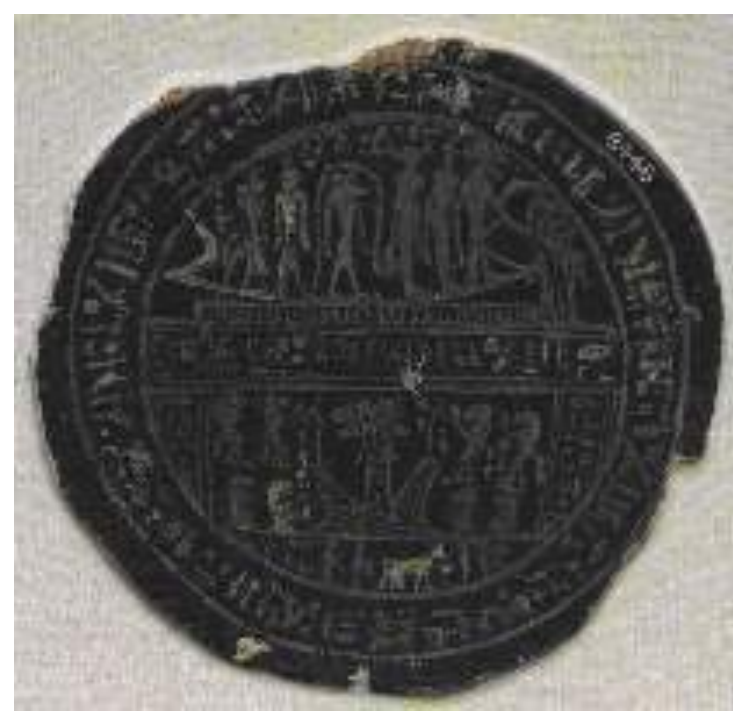

Figure (10)

Birch, S. (1884), P S B A 6, London, pp. 170-173, pl. without No.

Porter, B and R. Moss (1964), Vol.1, P.2, London, pp. 623624.

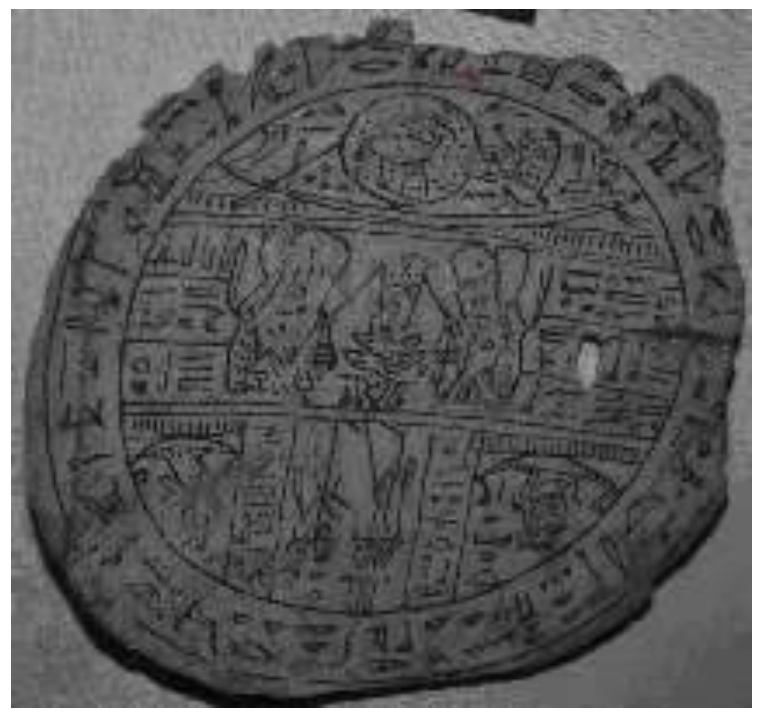

Figure (12)

Darssy, M. G. (1903), CG, Textes Et Dessins Magiques (No. 9401-9449), Cairo, pp. 50 - 52, Pl Xiii.

Egyptian Museum SR, JE. 


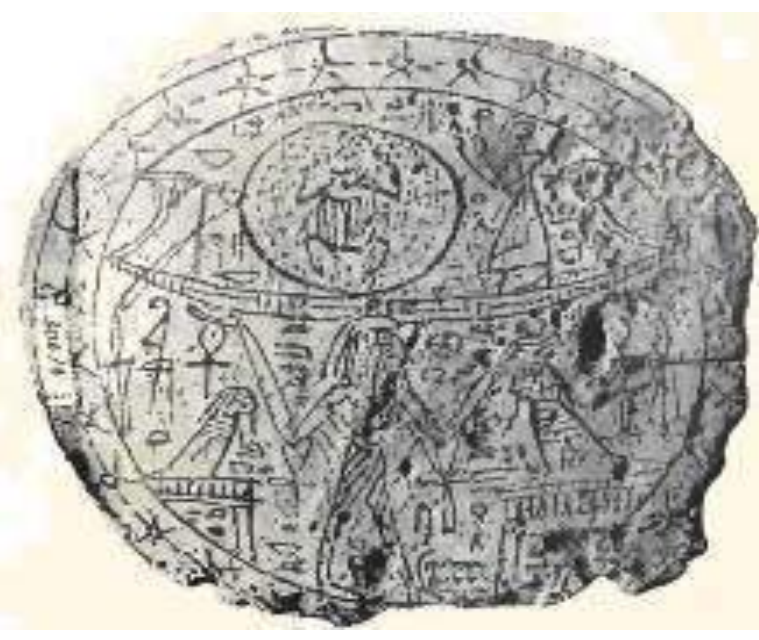

Figure (12) 'Verso'

Darssy, M. G. (1903), CG, Textes Et Dessins Magiques (No. 9401-9449), Cairo, pp. 50 - 52, Pl Xiii.

Egyptian Museum SR, JE.

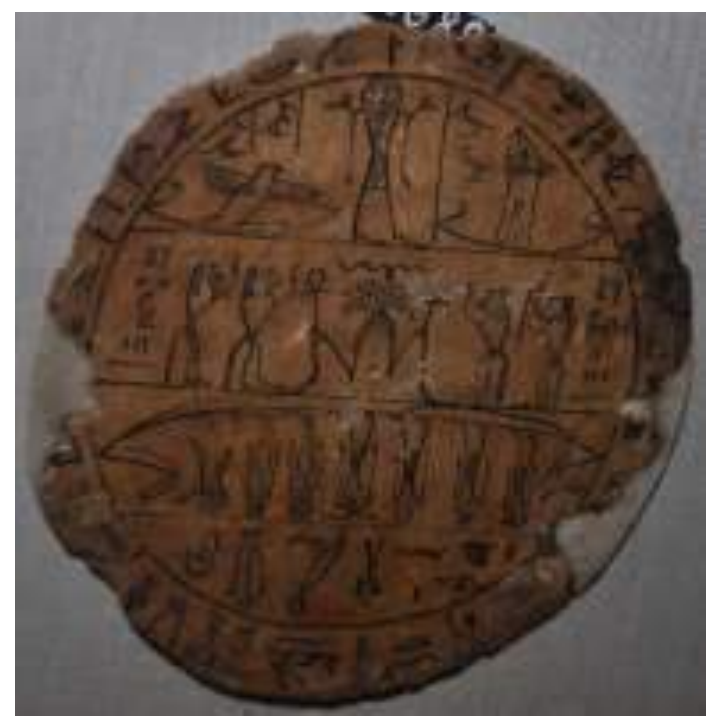

Figure (14)

Darssy, M. G. (1903), CG, Textes Et Dessins Magiques (No. 9401-9449), Cairo, p. 52, Pl Xiii. Egyptian Museum SR, JE.

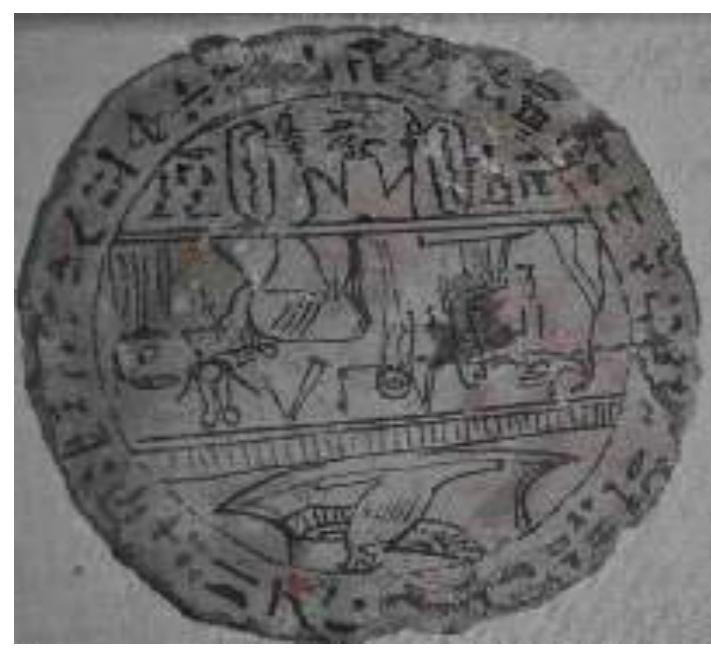

Figure (13)

Darssy, M. G. (1903), CG, Textes Et Dessins Magiques (No. 9401-9449), Cairo, p. 53, Pl Xiii. Egyptian Museum SR, JE.

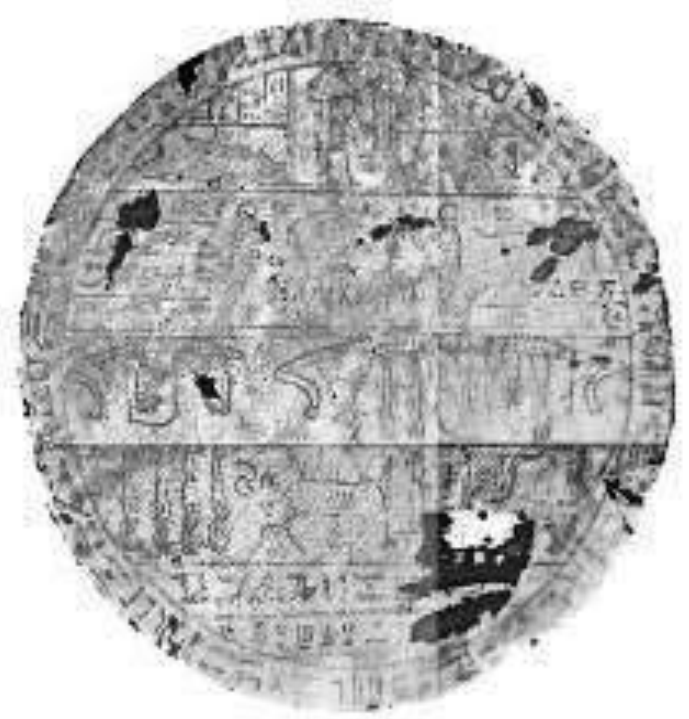

Figure (15)

Darssy, M. G. (1903), CG, Textes Et Dessins Magiques (No. 9401-9449), Cairo, pp. 54-56.

Egyptian Museum SR, JE. 


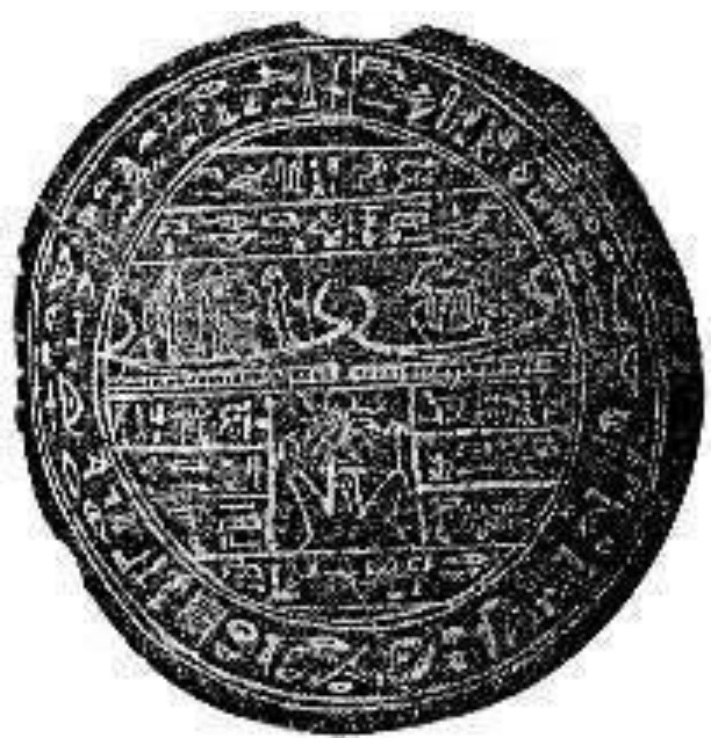

Figure (16|)

Darssy, M. G. (1903), CG, Textes Et Dessins

Magiques (No. 9401-9449), Cairo, pp. 49-50.

Egyptian Museum SR, JE.

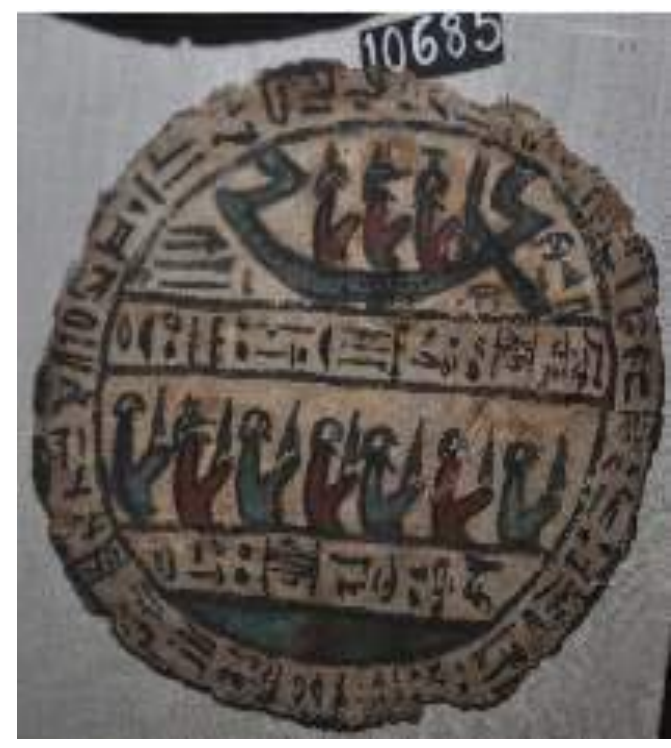

Figure (17)

Darssy, M. G. (1903), CG, Textes Et Dessins Magiques (No. 9401-9449), Cairo, pp. 53-54, Pl Xiii. Egyptian Museum SR, JE.

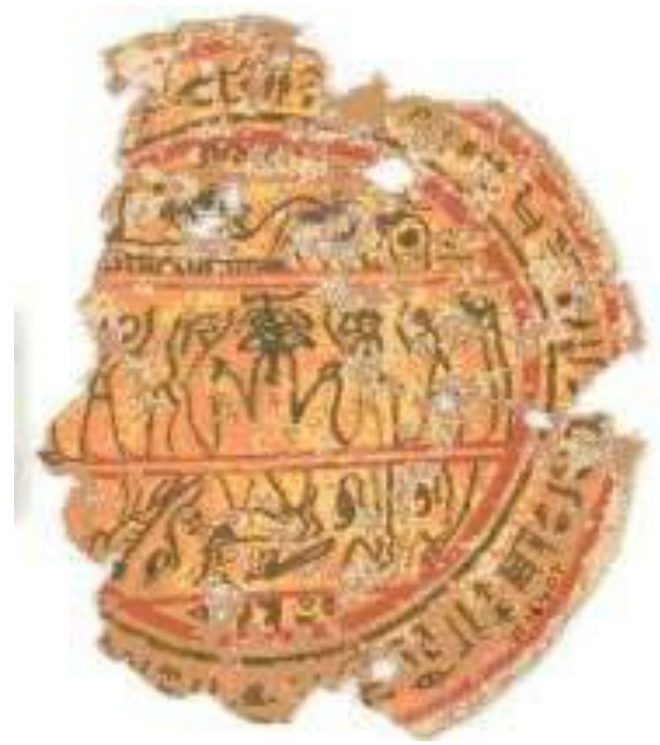

Figure (18)

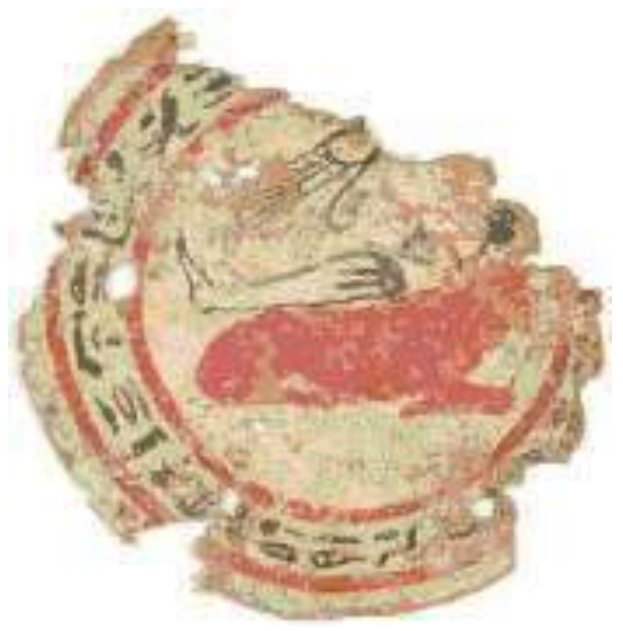

Figure (18) 'Verso'

Petrie, W, F. (1937), The Funeral Furniture of Egypt with Stone and Metal Vases, p. 25. Petrie, W, F. (1914), Amulets, London, p. 30, Fig. 134 a and b. 


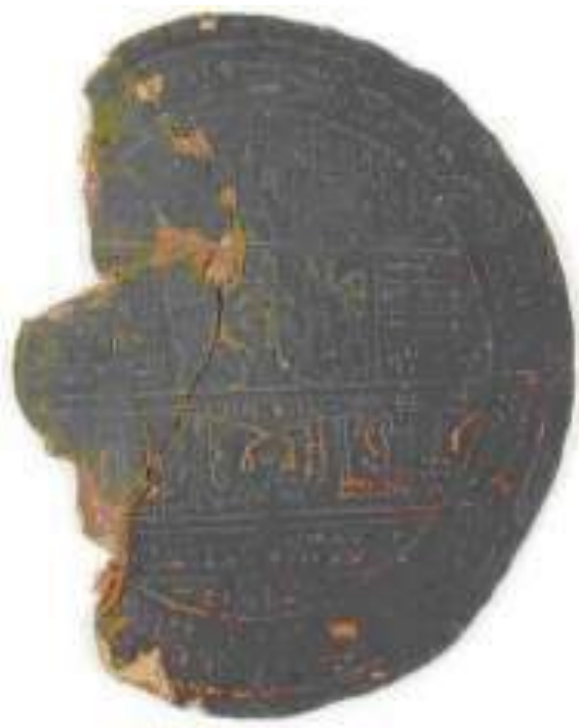

Figure (19)

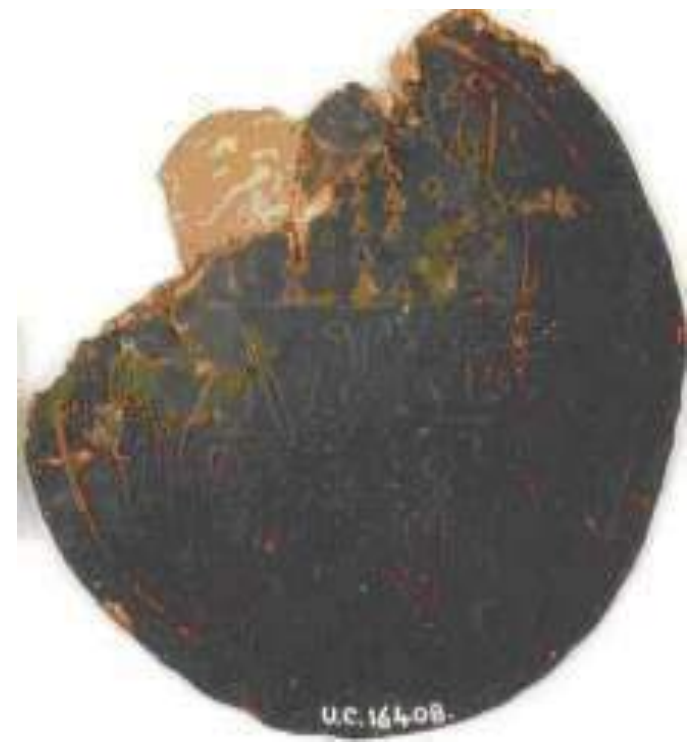

Figure (19) 'Verso'

Petrie, W, F. (1937), The Funeral Furniture of Egypt with Stone and Metal Vases, London, p. 25. Petrie, W, F. (1914), Amulets, London, p. 30, 134 b2 without Figure.

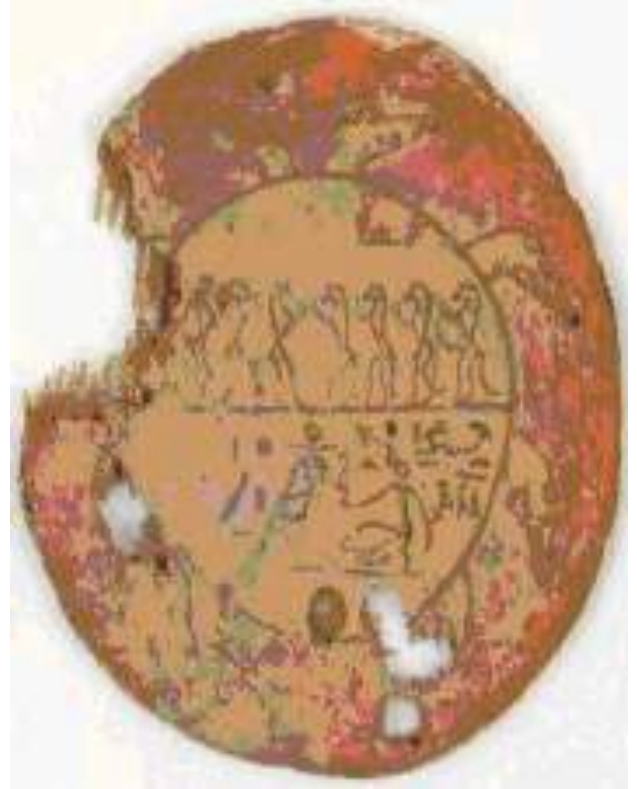

Figure (20)

Petrie, W, F. (1937), The Funeral Furniture of Egypt with Stone and Metal Vases, London, p. 2 Petrie, W, F. (1914), Amulets, London,p.30, 1 3 4 c

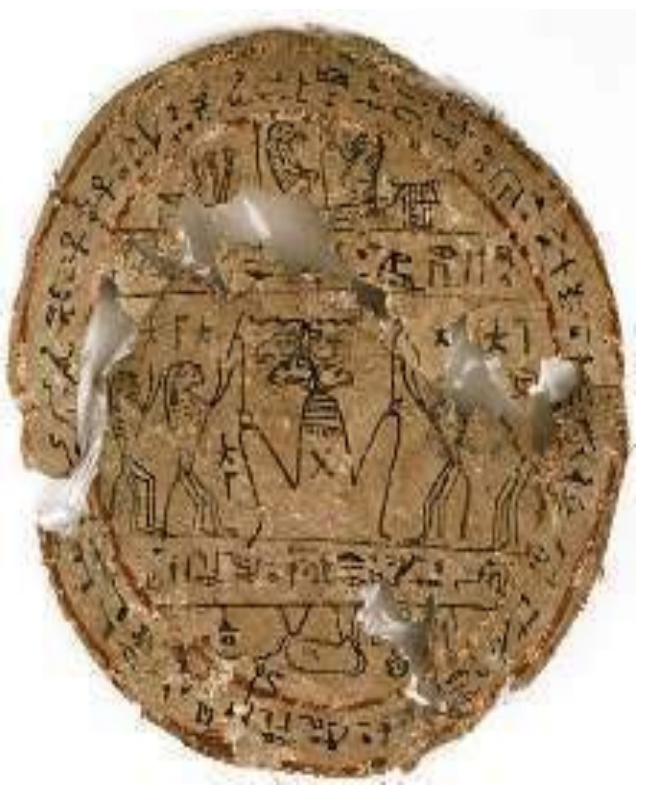

Figure (21)

Saleh, J. M.(1970), Les antiquités Égyptiennes de Zagreb, Paris, p.170, No. 889.

http://amz.academia.edu/IgorUrani\%C4\%87, Uranić, I., Three Hypocephali from Zagreb Collection, p. 5 (Last Accessed 2/1/2015). 


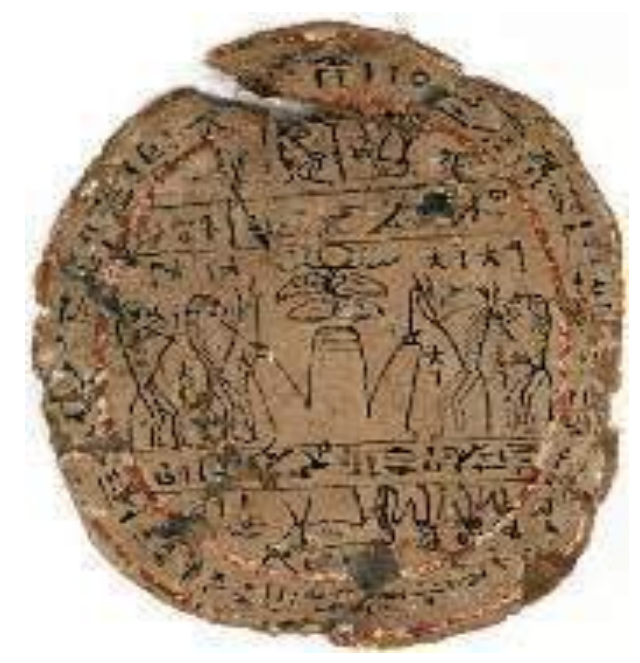

Figure (22)

Saleh, J. M. (1970), Les antiquités Égyptiennes de Zagreb, Paris, p.171, No. 890.

http://amz.academia.edu/IgorUrani\%C4\%87, Uranić, I., Three Hypocephali from Zagreb Collection, p. 6 (Last Accessed 2/1/2015).

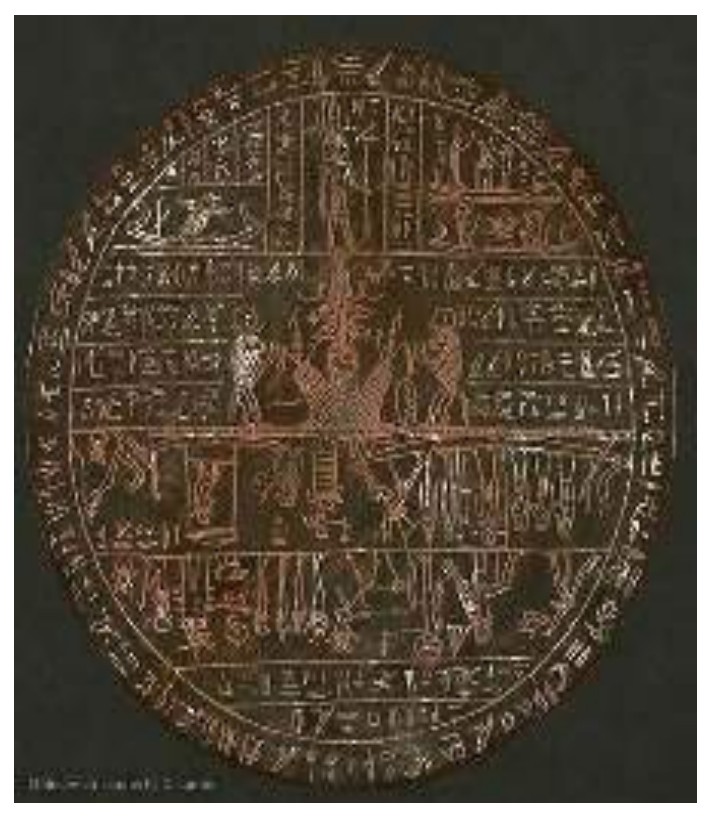

Figure (24)

http://www.louvre.fr/en/oeuvre-notices/hypocephalusirethorrou ( Last Accessed 25/1/2015).

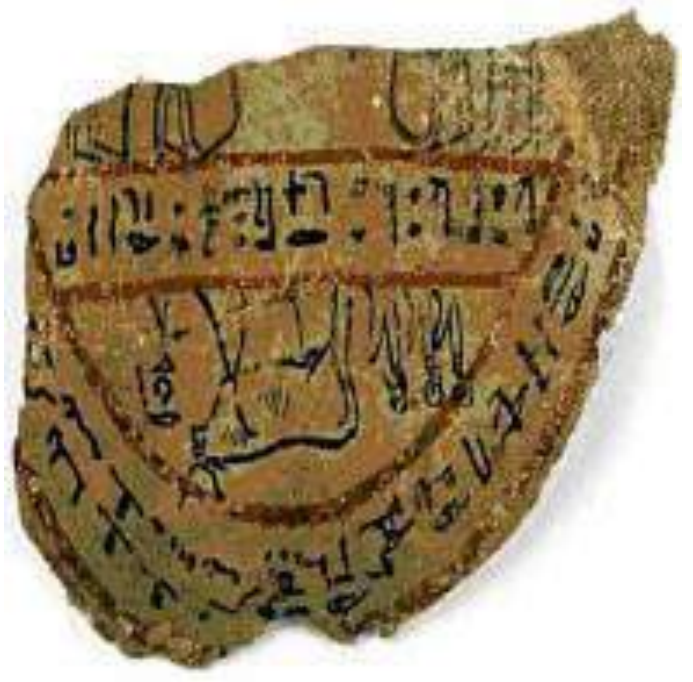

Figure (23)

Saleh, J. M. (1970|), Les antiquités Égyptiennes de Zagreb. Paris, p.172, No. 891.

http://amz.academia.edu/IgorUrani\%C4\%87,

Uranić, I., Three Hypocephali from Zagreb Collection, p. 7 (Last Accessed 2/1/2015).

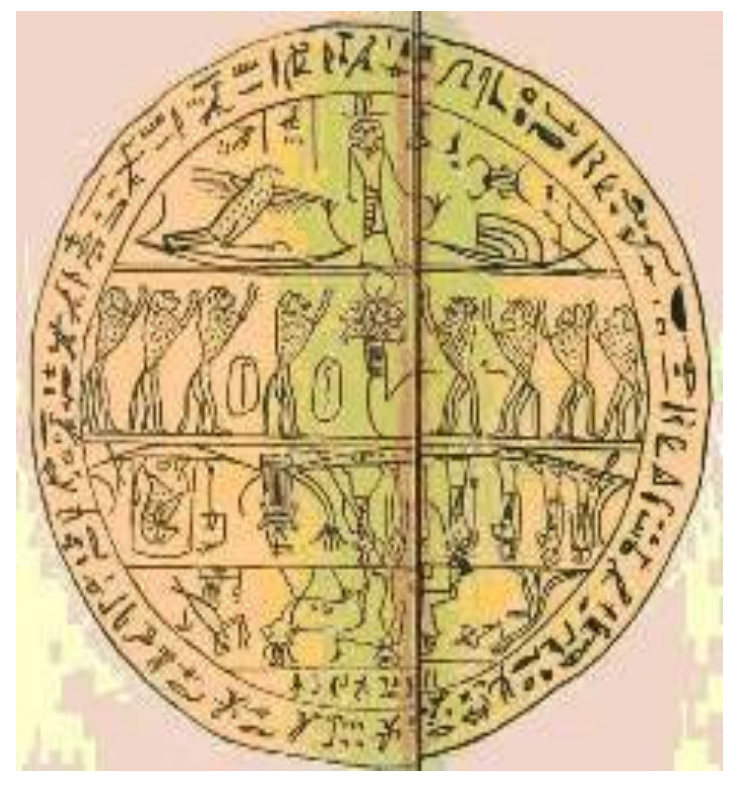

Figure (25)

Horrack P. J. (1884), P S B A 6, London, p. 126129, pl. without no. 


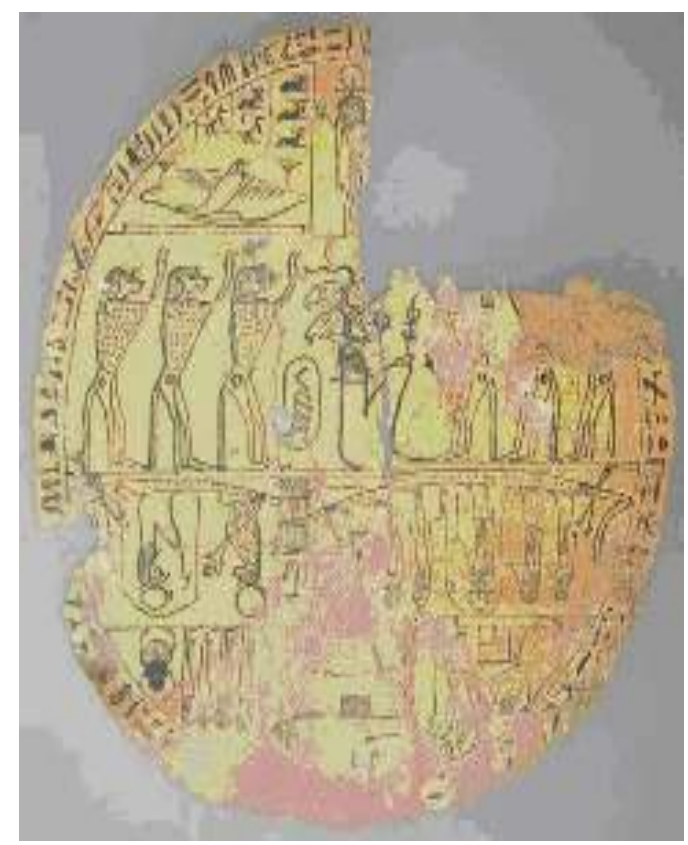

Figure (26)

http://www.penn.museum/collections/object/276962 (Last Accessed 20/1/2015).

Porter,B and R, Moss (1964), Vol. 1, P. 2, P. 611

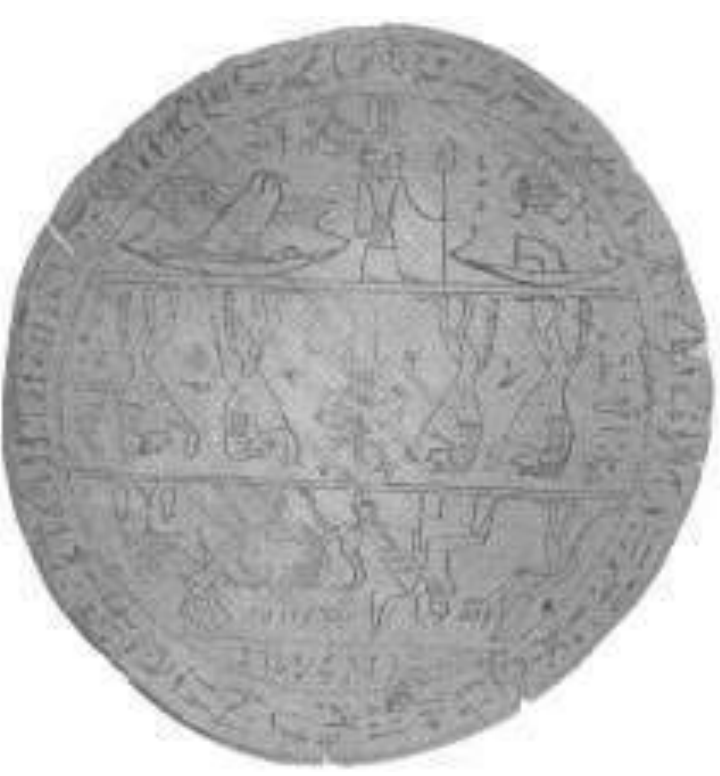

Figure (28)

Miatello, L. (2008), The Hypocephalus of Takerheb in Firenze and the Scheme of the Solar Cycle, SAK 37, p. 279, Fig. 1.

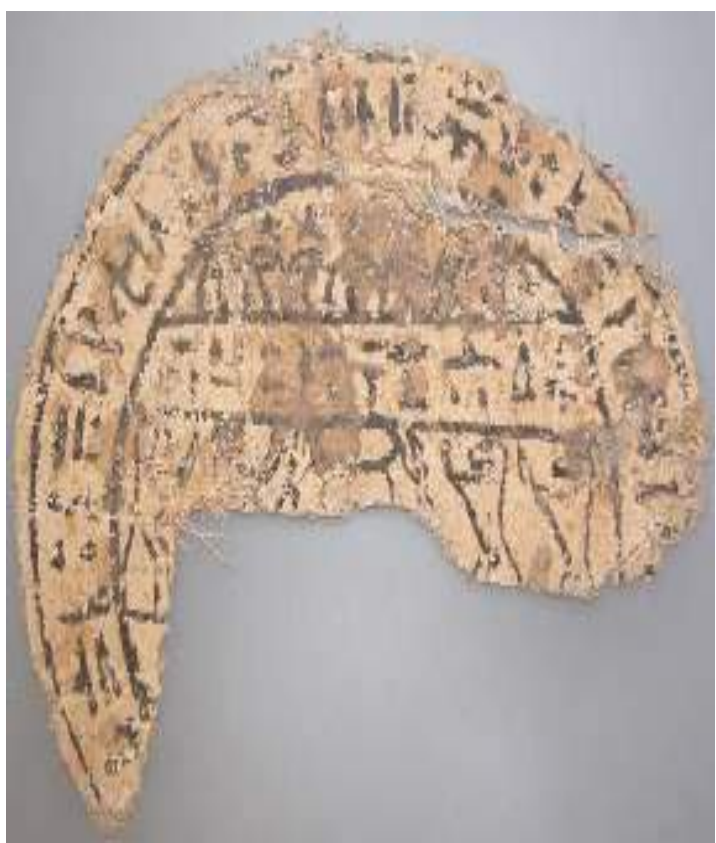

Figure (27)

http://www.penn.museum/collections/object/339351 (Last Accessed 20/1/2015).

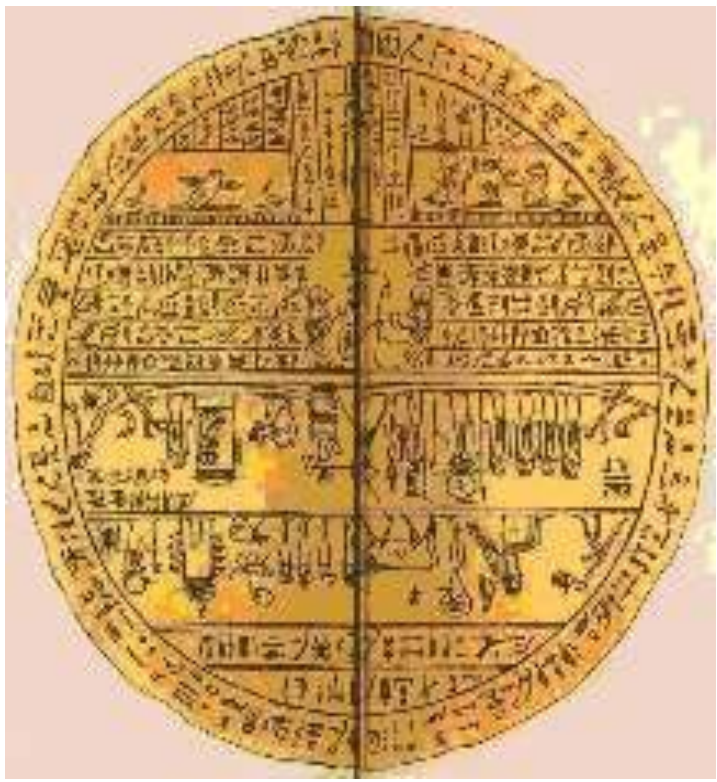

Figure (29)

Porter,B and R, Moss (1964), Vol. 1, P. 2, P.845. Birch, S. (1884), PSBA 6, London, p.37- 40 with pl (Meux, Collection).

Miatello, L. (2008), The Hypocephalus of Takerheb in Firenze and the Scheme of the Solar Cycle, SAK 37, p. 280, Fig. 2.

Budge, W., Egyptian Magic, London, 1901, p. 117, 119. 


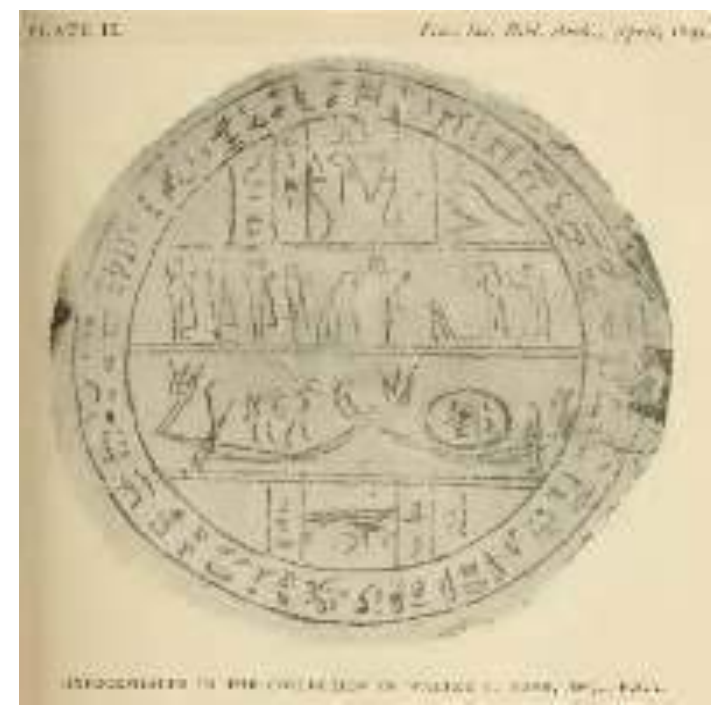

Figure (30)

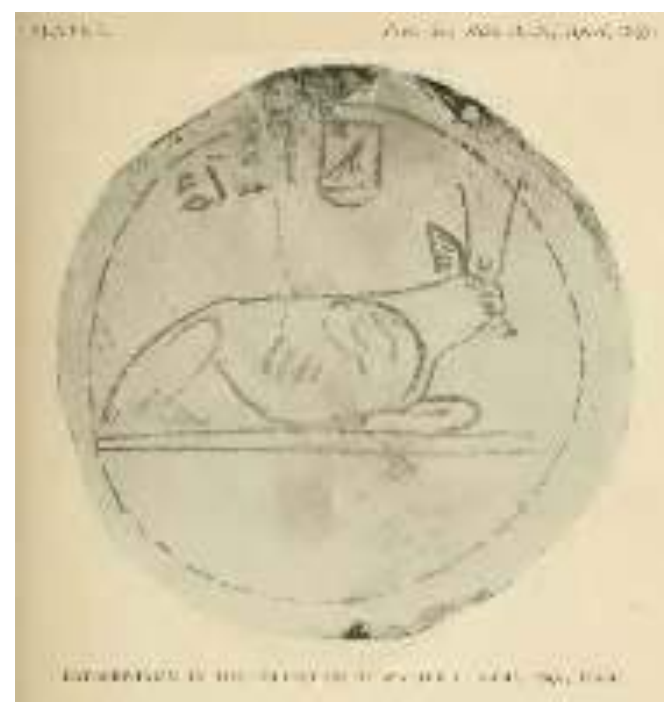

Figure (30) 'Verso'

Renouf, P.(1897), P.S.B.A 19, London, pp. 144-146, pl. i, ii.

Porter, B., and R. Moss (1964), Vol.1, P.2, London, P. 845.

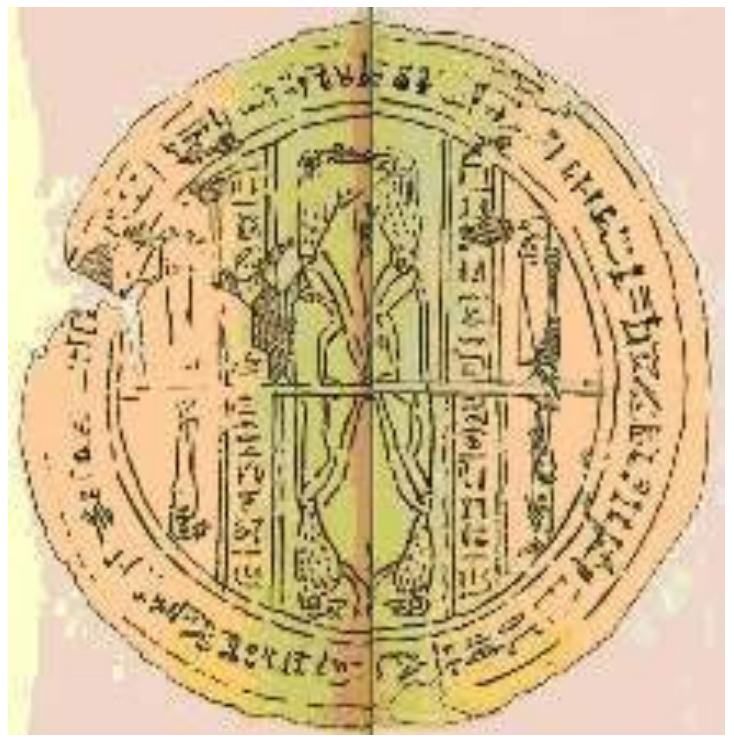

Figure (31)

Birch, S. (1885), P S B A 7, London, pp. 213, 214, pl. without No.

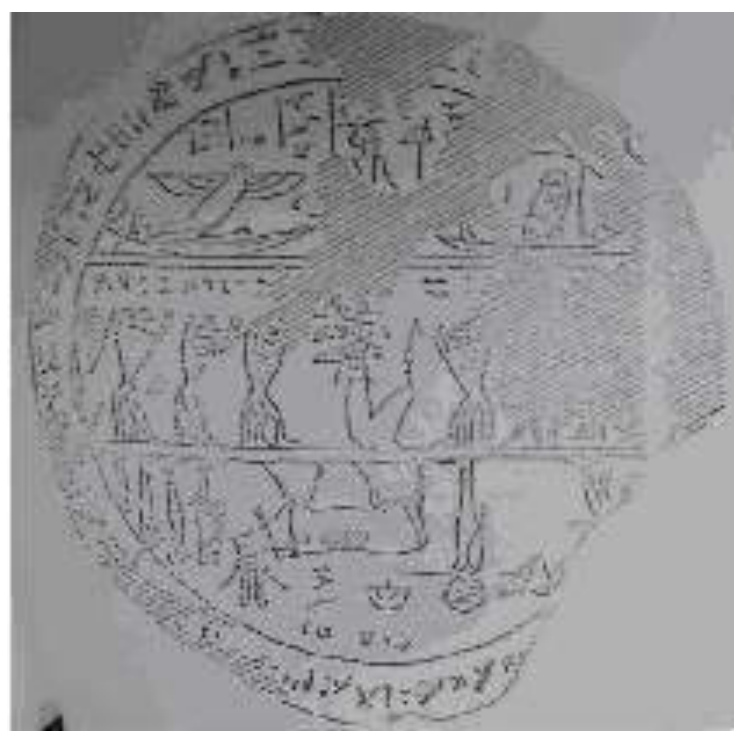

Figure (32)

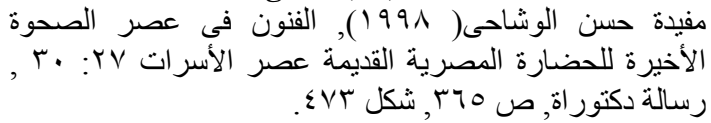




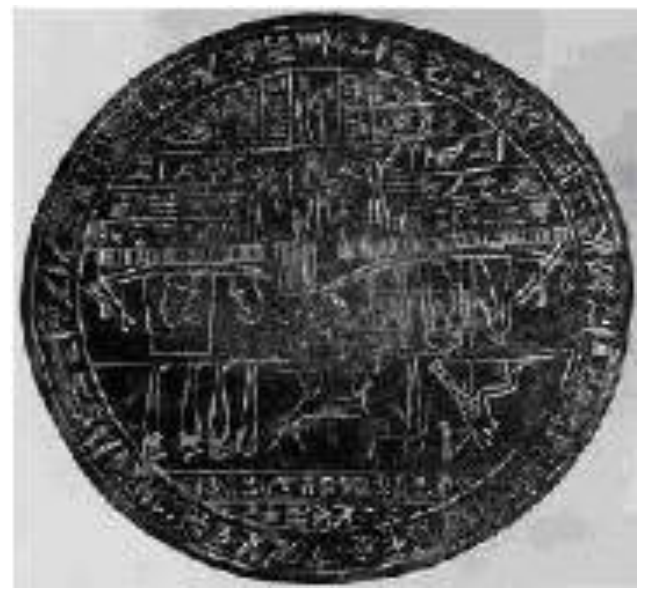

Figure (33)

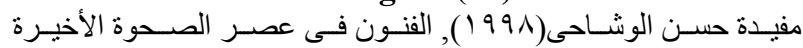

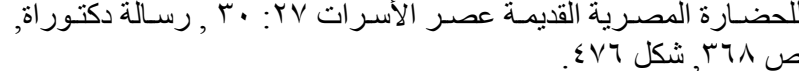

Petrie, W. M. (1902), Abydos I, London, pp. 49-51, pl. LXXVII, LXXIX Fig. 4.

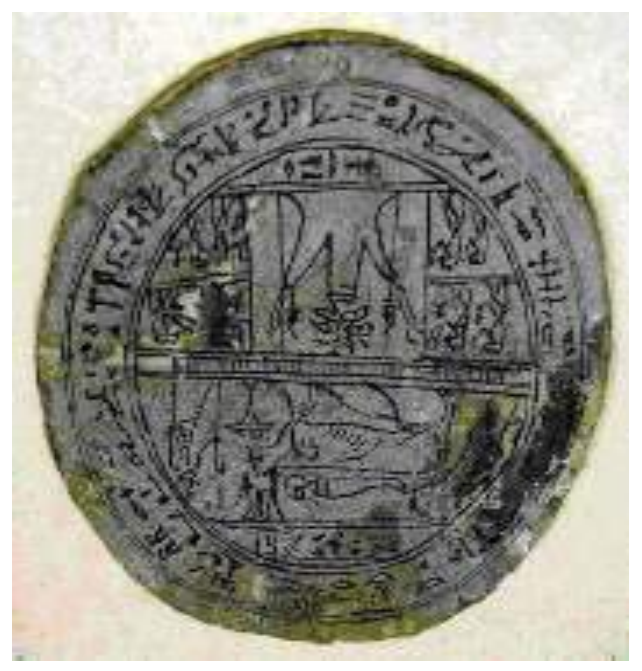

Figure (35)

http://www.ancientegypt.co.uk/ashmolean/pages/2005mar-11\%20472.htm ( Last Accessed 11/1/1015)

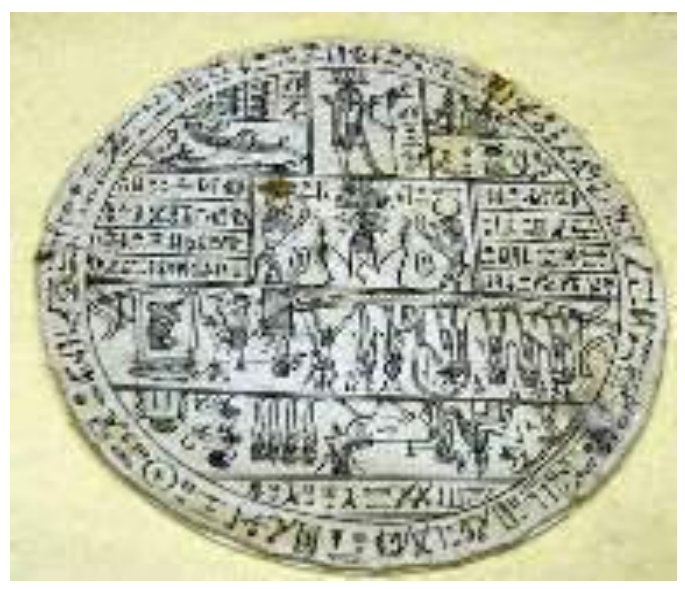

Figure (34)

http://www.ashmoleanprints.com/image/453787/amulet ic-disk-hypocephalus-made-for-tasheritenkhonsu ( Last Accessed 11/1/1015)

http://www.ancientegypt.co.uk/ashmolean/pages/2005mar-11\%20472.htm ( Last Accessed 11/1/1015)

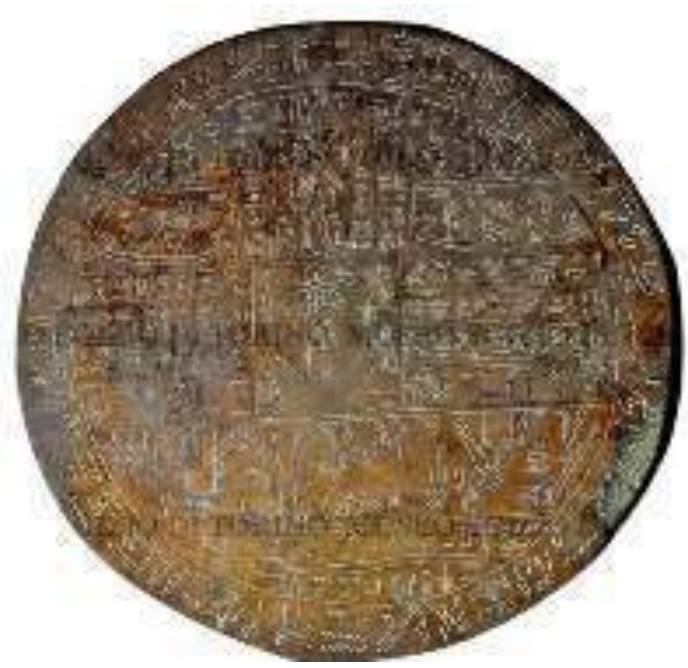

Figure (36)

Fabretti, A., A. Rossi and R.V. Lanzone (1882|), Regio Museo di Torino. Antichità Egizie, Stamperia Reale, Torino, n. 2319, p. 327. 


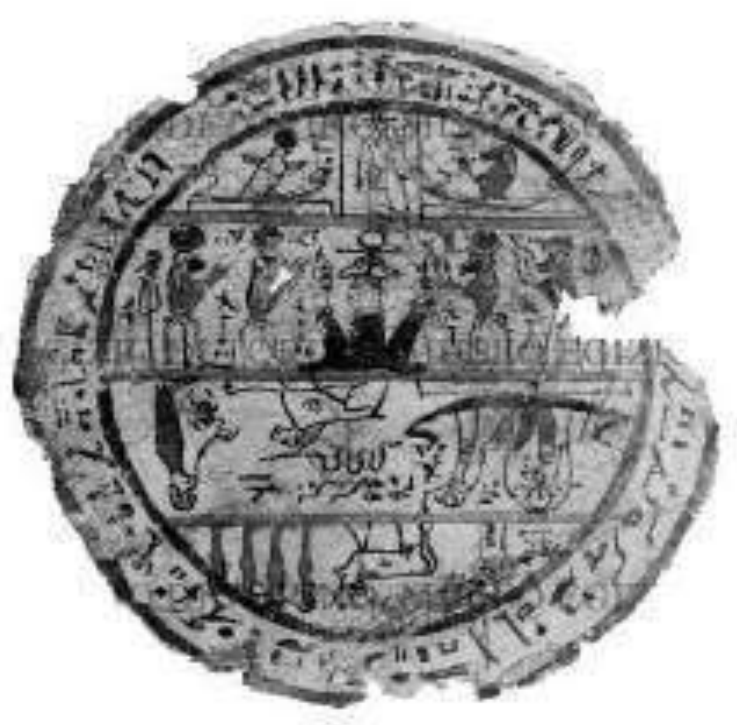

Figure (37)

Fabretti, A., A. Rossi and R.V. Lanzone (1882|), Regio Museo di Torino. Antichità Egizie, Stamperia Reale, Torino, n. 2323, p. 328.

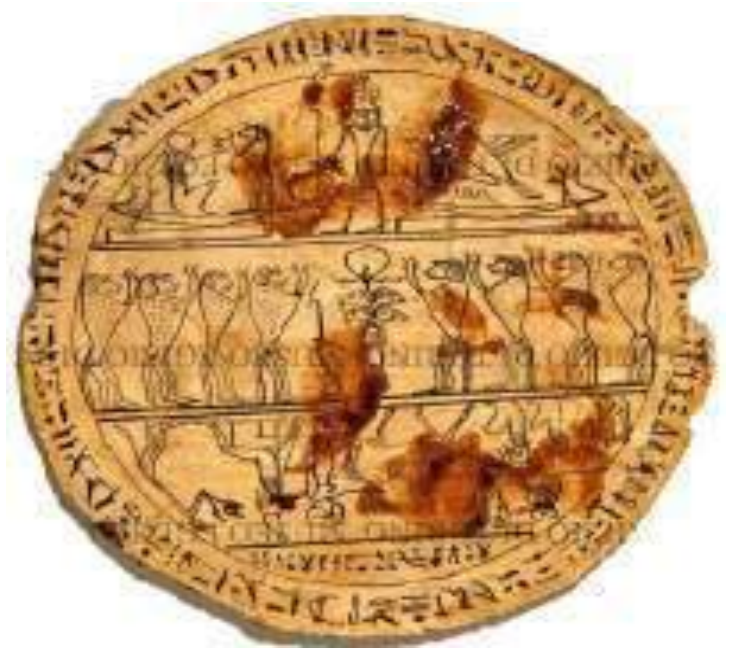

Figure (39)

Fabretti, A., A. Rossi and R.V. Lanzone (1882|), Regio Museo di Torino. Antichità Egizie, Stamperia Reale, Torino, n. 2324, p. 329.

Mekis,T. (2011), L' équipement funéraire de la pretresse thébaine Nestaneteretten, Chronique D' Egypte LXXXVI, Brussel, p. 60 - 66 ,81, Fig. 5.

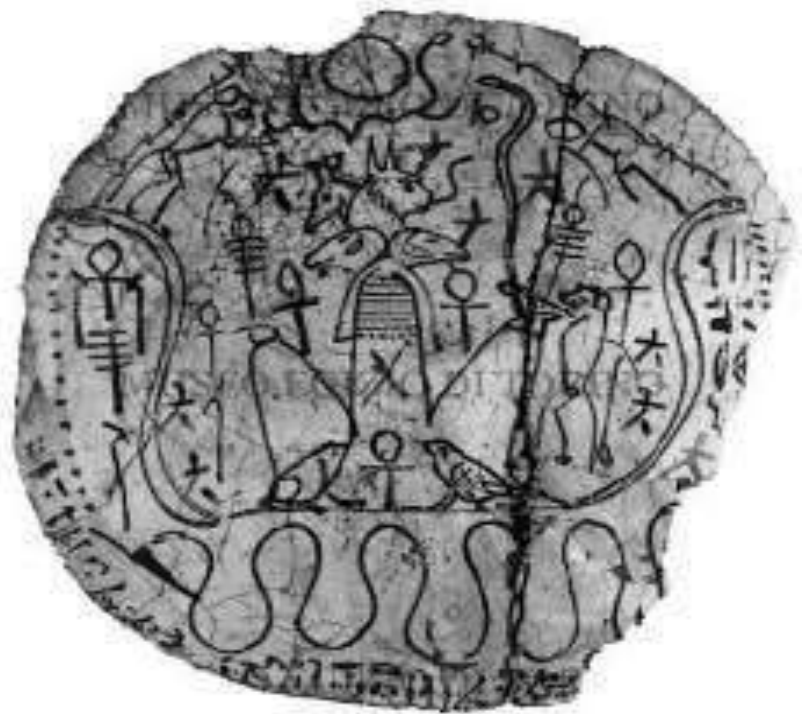

Figure (38)

Fabretti, A., A. Rossi and R.V. Lanzone (1882|), Regio Museo di Torino. Antichità Egizie, Stamperia Reale, Torino, 1882, n. 2326, p. 329.

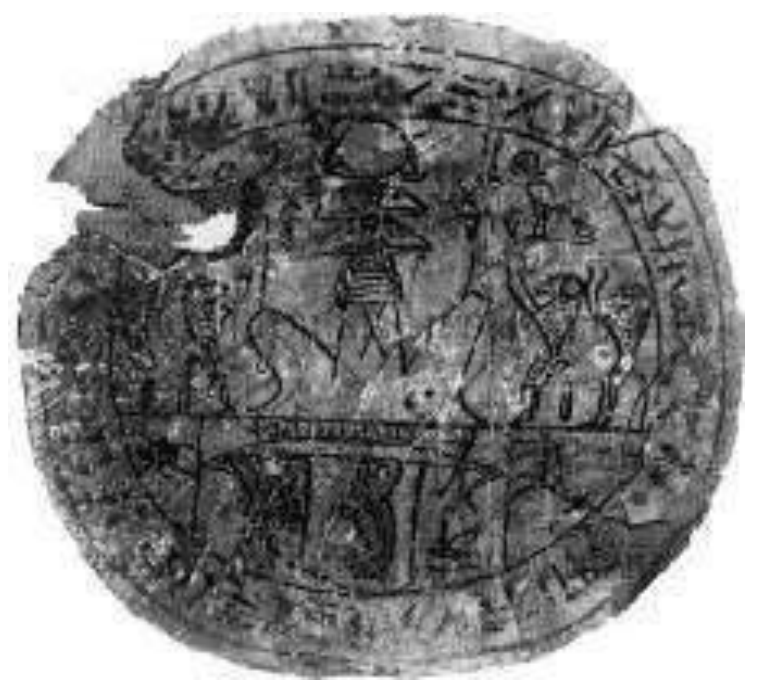

Figure (40)

Fabretti, A., A. Rossi and R.V. Lanzone (1882|), Regio Museo di Torino. Antichità Egizie, Stamperia Reale, Torino, 1882, n. 2325, p. 329.

Henri , W., (1954) Statue de Hor-néfer au Musée des Beaux-arts de Lausanne, BIFAO 54, p. 215. 


\section{Endnotes}

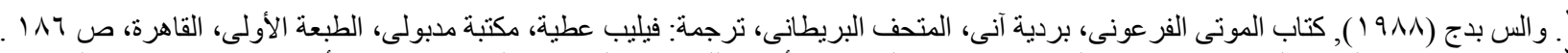

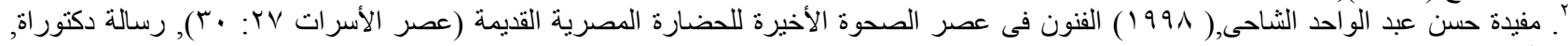

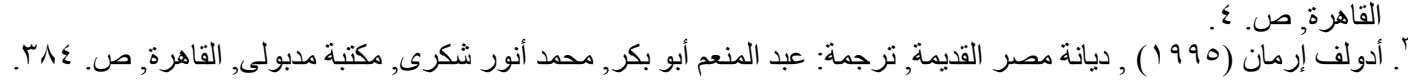

4. Scott, N, E. (1951), The Metternich Stela, The Metropolitn Museum of Art Bulletin, Vol. 9, No. 8, pp. 201-217; مفيدة حسن عبد الواحد الوشاحى, مرجع سبق ذكرة, ص.

6. Andrews, C. (1990), Ancient Egyptian Jewellery, UK, p. 7; المرجع السابق, ص. .

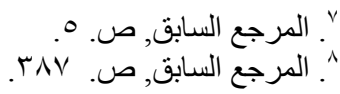

9 . Andrews, C.( 2001), Amulets, The Oxford Encyclopedia of Ancient Egypt, Vol. I, Oxford, pp. 75 - 82; Bonnet, H. (1952), Reallexikon Der ÄgyptischenReligionsgeschichte, Berlin, pp. 26 - 29, Figs. 1-18; Petri W.F. (1914), Amulets, London, p. 1; Pinch, G. (1994), Magic in Ancient Egypt, London, pp. 104, 105; Klasens, A. (1975), Amulet,

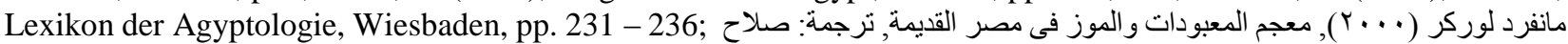

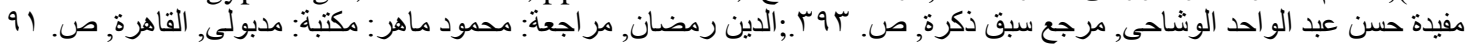

10. Andrews, C., Amulets, op. cit., pp. 75 - 82; Andrews, C. (1994), Amulets of Ancient Egypt, London, pp. 7, 8; Faulkner, R. O. (1990), The Ancient Egyptian Book the Dead, Texas, p. 54; http://amz.academia.edu/IgorUrani\%C4\%87Uranić, I.,Three Hypocephali From Zagreb Collection, p. 1. (Last

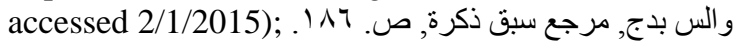

11. Budge, W. (1901), Egyptian Magic, London, pp. 114 - 116; Allen, T. G. (1974), The Book of the Dead or Going Forth by Day, Studies in Ancient Oriental Civilization No. 37, Chicago, p. 157; Petri W.F., op. cit., No. 134, p. 30; أدولف إرمان, مرجع سبق ذكرة, ص.

12. Rhodes,M. D. (1997), The Joseph Smith Hypocephalus... Twenty Years Later, USA, retrieved 2014, p. 1.

13. Loc. cit.; Birch, S. (1885), PSPA 7, London, p.214.

14. Rhodes, M. D., loc. cit.; Budge, W., op. cit., pp. 115; Lepsius,R. (1842),Das Todtenbuch der Ägypter,Leipzig, Chapter 162, line 10, p. 24, pl. LXXVII; Wiedmann, A. (1897), Religion of the Ancient Egyptians, London, pp.298, 299; http://amz.academia.edu/IgorUrani\%C4\%87Uranić, I.,Three Hypocephali From Zagreb Collection, p. 1. (Last accessed 2/1/2015).

${ }^{15}$. Allen, T. G., op. cit., p. 157; Rhodes,M. D., loc. cit.; Lepsius, R., loc. cit.; Birch,,S.(1884), PSBA 6, London, p. 38; Kirchheim, D, K.(1980), Kopftafel, Lexikon der Agyptology, III,Wiesbaden, p. 693; http://amz.academia.edu/IgorUrani\%C4\%87Uranić, I.,Three Hypocephali From Zagreb Collection, p. 1. (Last أدولف إرمان, مرجع سبق ذكرة, ص.

16. Budge, W., op. cit., pp. 114,115; Rhodes, M. D., op. cit., p. 1, 2.(Translation of Chapter 162 of the Book of the Dead, see: p. 13, 14).

17 . Lepsius, R.,op. cit., p. 24.

${ }^{18}$. Allen, T. G., op. cit., p 157; Rhodes,M. D., op. cit., p. 2; Naville, E.(1886), Das ÄgyptischeTodtenbuch der XVIII. bis XX. Dynastie, Berlin, p.184.

${ }^{19}$. Rhodes,M. D., Ibid., p. 1; http://amz.academia.edu/IgorUrani\%C4\%87Uranić, I.,Three Hypocephali From Zagreb Collection, p. 1. (Last accessed 2/1/2015).

20. Birch,,S., PSBA 6, op. cit., p. 38; Rhodes,M. D., loc. cit.

${ }^{21}$. Rhodes, M. D., loc. cit.; Wiedmann, A., op. cit., p. 299; http://amz.academia.edu/IgorUrani\%C4\%87Uranić, I.,Three

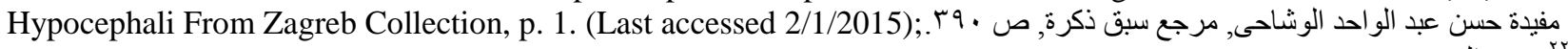

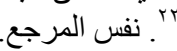

23. Markwitz, Y., and P. Lacovara (2001), Bronze, TheOxford Encyclopedia in Ancient Egypt, Vol. I, Oxford, p. 201.

${ }^{24}$. Wilkinson, R. H. (1994), Symbol and Magic in Egyptian Art, London, p, 83; Wilkinson, R. H. (2001), Symbols, The Oxford Encyclopedia in Ancient Egypt, Vol. III, Oxford, p. 332.

${ }^{25}$. Rhodes, M. D., op. cit., p. 1; Renouf, P. (1897), PSBA 19, London, p. 145.

26. http://amz.academia.edu/IgorUrani\%C4\%87Uranić, I.,Three HypocephaliFrom Zagreb Collection, p. 2. (Last accessed 2/1/2015).

27. Rhodes, M. D., op. cit., p. 12.

28. Bonnet, H., op. cit., pp. 223-25, 247.

29. http://amz.academia.edu/IgorUrani\%C4\%87Uranić, I.,Three HypocephaliFrom Zagreb Collection, p. 3. (Last accessed 2/1/2015).

${ }^{30}$. Rhodes, M. D., op. cit., p. 4, 5; Brown, F. (1968), Driver, S. R. and Briggs, C., Hebrew and English Lexicon of the Old Testament, Oxford, 1061.

31. http://amz.academia.edu/IgorUrani\%C4\%87Uranić, I.,Three HypocephaliFrom Zagreb Collection, pp. 3, 4 (Last accessed 2/1/2015).

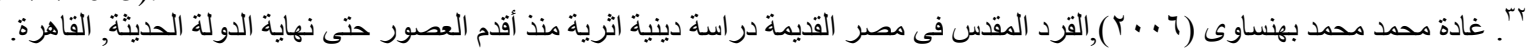

${ }^{33}$.Wilkinson, R. H. (1994), Reading Egyptian Art, London, p. 73; Kessler, D., loc. cit.; Rhodes, M. D., op. cit., p. 8. 
غادة محد محمد بهنساوى, مرجع سبق ذكرة, ص. rrr.

35. Wilkinson, R. H., loc. cit.

${ }^{36}$. Wilkinson, R. H., loc. cit.

${ }^{37}$. Wilkinson, R. H., Ibid., Fig. 4.

${ }^{39}$. Wilkinson, R. H., op. cit, p. 73.

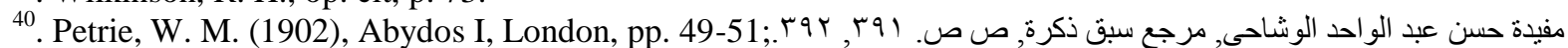

${ }^{41}$. Porter, B. and R. Moss (1964), Vol. 1, P.2, London, p. 845.

42 . Birch, S., P S B A 6, op. cit., p. 185-187, Fig after p. 186.

43. Ibid., pp. 129 -131; Wilkinson, R. H., symbol and magic in Egyptian Art, op. cit, pp. 72, 73; Shaw, I. and P. Nicholson (2002), The British Museum of Ancient Egypt, Cairo, pp. 137, 138.

44 . Birch, S., Ibid., pp. $129-131$.

45 . Ibid., pp. 185-187.

${ }^{46}$. http://www.britishmuseum.org/research/collection_online/collection_object_details.aspx?objectId=123478\&partId=1 \&searchText=Hypocephalus+\&images=true\&page=1( Last Accessed 27/1/2015)

47 . Wiedemann, A. op. cit., p. 298.

${ }^{48}$. Birch, S., P S B A 6, op. cit., p. 106-107, 129-131.

49. Ibid., pp. 170-173; Porter, B and R. Moss, op. cit., pp. 623-624.

مفيدة حسن عبد الواحد الوشاحى, مرجع سبق ذكرة, ص.

51. Darssy, M. G. (1903), CG, TextesEtDessinsMagiques (No. 9401-9449), Cairo, pp. 50-52.

52 . Ibid., p. 53.

53 . Ibid., p. 52.

54 . Ibid., pp. 54-56.

55 . Ibid., pp. 49-50.

56. Ibid., pp. 53-54.

57. Petrie, W, F. (1937), The Funeral Furniture of Egypt with Stone and Metal Vases, pp. 25; Petrie, W, F. (1914), Amulets, op. cit., p. 30.

${ }^{58}$. Petrie, W, F., The Funeral Furniture of Egypt with Stone and Metal Vases, Ibid.; Petrie, W, F. (1914), Amulets, Ibid.

${ }^{59}$. Petrie, W, F., The Funeral Furniture of Egypt with Stone and Metal Vases, Ibid.; Petrie, W, F. (1914), Amulets, Ibid.

${ }^{60}$.Saleh, J. M.(1970), Les antiquitésÉgyptiennes de Zagreb, Paris, p.170, No. 889; http://amz.academia.edu/IgorUrani\%C4\%87, Uranić, I.,Three Hypocephali from Zagreb Collection, p. 5 (Last Accessed 2/1/2015).

${ }^{61}$. Saleh, J. M., Ibid., p.171, No. 890; http://amz.academia.edu/IgorUrani\%C4\%87, Uranić, I.,Three Hypocephali from Zagreb Collection, p. 6 (Last Accessed 2/1/2015).

${ }^{62}$. Saleh, J. M.,Ibid., p.172, No. 891; http://amz.academia.edu/IgorUrani\%C4\%87, Uranić, I.,Three Hypocephali from Zagreb Collection, p. 7 (Last Accessed 2/1/2015).

${ }^{63}$. http://www.louvre.fr/en/oeuvre-notices/hypocephalus-irethorrou(Last Accessed 25/1/2015).

${ }_{64}^{64}$ Horrack P. J. (1884), P S B A 6, London, p. 126-129.

65. Porter, B and R, Moss, op. cit.,p. 611; http://www.penn.museum/collections/object/276962 (Last Accessed 20/1/2015).

66. http://www.penn.museum/collections/object/339351(Last Accessed 20/1/2015).

${ }_{68}^{67}$. Miatello, L. (2008), TheHypocephalus of Takerheb in Firenze and the Scheme of the Solar Cycle, SAK 37, p. 279.

${ }^{68}$. Porter,B and R, Moss, op. cit., p. 845; Birch, S. (1884), PSBA 6, op. cit., p.37- 40; Miatello, L., Ibid., p. 280; Budge, W., op. cit.,p. 117, 119.

${ }^{69}$. Renouf, P., op. cit., pp. 144-146; Porter, B., and R. Moss, Ibid., p. 845.

${ }^{70}$. Birch, S., P S B A 7, op. cit., pp. 213, 214;

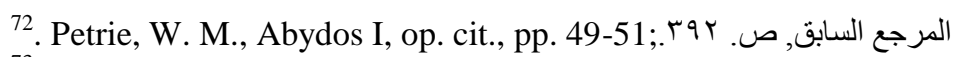

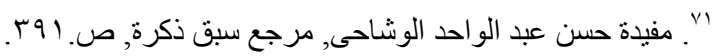

${ }^{73}$.http://www.ashmoleanprints.com/image/453787/amuletic-disk-hypocephalus-made-for-tasheritenkhonsu(Last Accessed 11/1/1015); http://www.ancient-egypt.co.uk/ashmolean/pages/2005-mar-11\%20472.htm(Last Accessed $11 / 1 / 1015)$

${ }^{74}$. http://www.ancient-egypt.co.uk/ashmolean/pages/2005-mar-11\%20472.htm(Last Accessed 11/1/1015)

75. Fabretti, A., A. Rossi and R.V. Lanzone (1882|), RegioMuseo di Torino.AntichitàEgizie, StamperiaReale, Torino, n. 2319, p. 327.

${ }^{76}$. Fabretti, A., A. Rossi and R.V. Lanzone, Ibid., n. 2323, p. 328.

77 . Fabretti, A., A. Rossi and R.V. Lanzone, Ibid., n. 2326, p. 329.

78. Fabretti, A., A. Rossi and R.V. Lanzone, Ibid., n. 2324; Mekis,T. (2011), L' équipementfunéraire de la pretressethébaineNestaneteretten, Chronique D' Egypte LXXXVI, Brussel, p. 60 - 66,81 .

${ }^{79}$. Fabretti, A., A. Rossi and R.V. Lanzone, Ibid., n. 2325; Henri, W., (1954) Statue de Hor-néfer au Musée des Beauxarts de Lausanne, BIFAO 54, p. 215. 
${ }^{80}$. Radwan, A.(1975), Der Kŏnigsname: EpigraphischeszumgöttlichenKönigtumimAltenÄgypten, SAK 2, Doc. 49, 50; Hornung, E. (1982), Conceptions of God in Ancient Egypt, New York, pp. 91-99; Wilkinson, R. H. (2003), The Complete Gods and Goddesses, London, p.95; Kakosy, L.(1966), Prophecies of Ram Gods, ActaOrientalia Academia ScientiarumHungaricae, T.19, Fasc.3, pp.341 - 358.

${ }^{81}$. Wilkinson, R. H., Ibid. pp. 32, 194.

${ }^{82}$. Bonnet, H., op. cit., 1952, pp. 137, 38; Rhodes,M. D., op. cit., p.8;

${ }^{84}$. Wilkinson, R. H., The Complete Gods and Goddesses, op. cit., p. 95

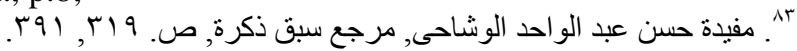

85. Wilkinson, R. H., Symbols and Magic in Ancient Egypt, op. cit., pp.126- 147.

86. http://amz.academia.edu/IgorUrani\%C4\%87Uranić, I.,Three Hypocephali from Zagreb Collection, pp. 7, 8(Last accessed 2/1/2015)

${ }^{87}$.Wilkinson, R. H., The Complete Gods and Goddesses, op. cit., p.88; http://amz.academia.edu/IgorUrani\%C4\%87Uranić, I.,Three Hypocephali from Zagreb Collection, pp. 11(Last

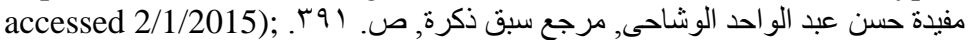

${ }^{88}$. Wilkinson, R. H., Reading Egyptian Art, op. cit, p.113.

${ }^{89}$. Petrie, W. M., Abydos I, op. cit., p. 50; Bonnet, op. cit., p. 389; Shorter,A,W. (1935), The God Nehebkau, JEA XXI,

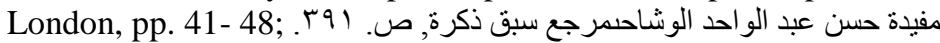

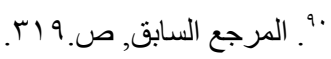

\section{وسادة رؤوس الموتى فى الاياتة المصرية القديمة}

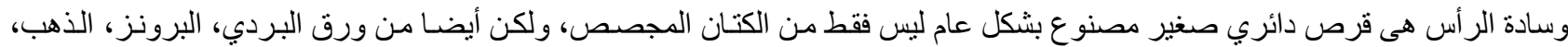

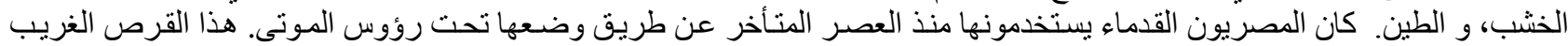

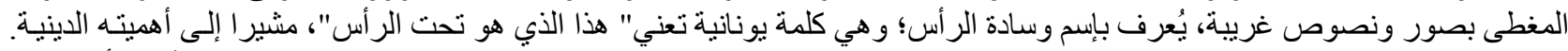

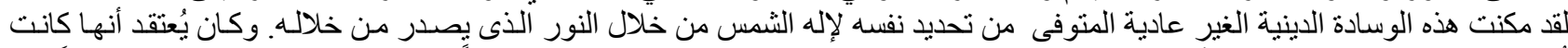

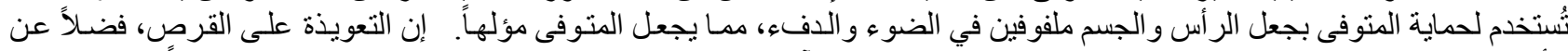

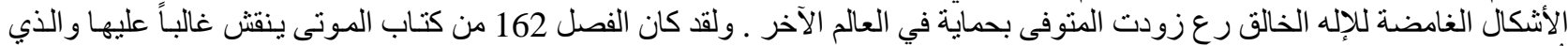

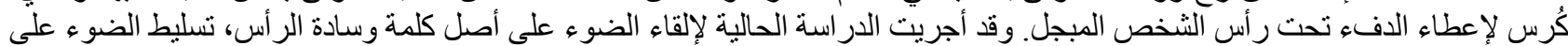

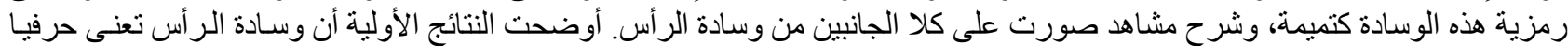

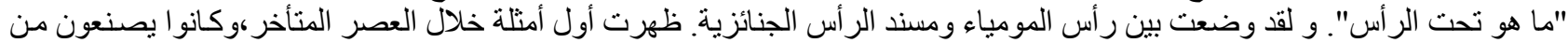

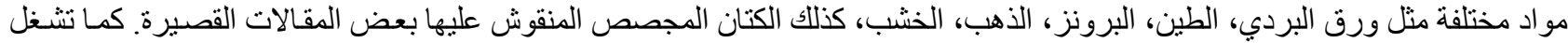
النقوش الهيرو غليفية إطار القرص بـ بالكامل. الكلمات الدالة: وسادة الر أس، قرص مستدير، العصر المتأخر، تميمة، الديانة المصرية القديمة، كتاب الموتى 